\title{
Narrow dispersed linear polyethylene using cobalt catalysts bearing cycloheptyl- fused bis(imino)pyridines; probing the effects of ortho-benzhydryl substitution
}

\author{
Chantsalnyam Bariashir, a,b Zheng Wang, ${ }^{\text {a,b }}$ Hongyi Suo, ${ }^{\mathrm{a}, \mathrm{b}}$ Muhammad Zada, ${ }^{\mathrm{a}, \mathrm{b}}$ Gregory A. \\ Solan, ${ }^{* a, c}$ Yanping Ma, ${ }^{\text {a }}$ Tongling Liang ${ }^{\mathrm{a}}$ and Wen-Hua Sun*a,b,d
}

\footnotetext{
${ }^{a}$ Key Laboratory of Engineering Plastics and Beijing National Laboratory for Molecular Science, Institute of Chemistry, Chinese Academy of Sciences, Beijing 100190, China.

${ }^{\mathrm{b}}$ CAS Research/Education Center for Excellence in Molecular Sciences, University of Chinese Academy of Sciences, Beijing 100049, China.

c Department of Chemistry, University of Leicester, University Road, Leicester LE1 7RH, UK.

${ }^{d}$ State Key Laboratory for Oxo Synthesis and Selective Oxidation, Lanzhou Institute of Chemical Physics, Chinese Academy of Sciences, Lanzhou 730000, China.
}

\begin{abstract}
The cycloheptyl-fused cobalt(II) chloride complexes, $\quad\left[2,3: 5,6-\left\{\mathrm{C}_{4} \mathrm{H}_{8} \mathrm{C}\left(\mathrm{N}\left(2-\mathrm{R}^{1}-4-\mathrm{R}^{2}-6-\right.\right.\right.\right.$ $\left.\left.\left.\left.\left(\mathrm{CHPh}_{2}\right) \mathrm{C}_{6} \mathrm{H}_{2}\right)\right)\right\}_{2} \mathrm{C}_{5} \mathrm{HN}\right] \mathrm{CoCl}_{2}\left(\mathrm{R}^{1}=\mathrm{R}^{2}=\mathrm{Me} \mathbf{C o 1}, \mathrm{R}^{1}=\mathrm{Me}, \mathrm{R}^{2}=\mathrm{CHPh}_{2} \mathbf{C o 2}, \mathrm{R}^{1}=\mathrm{Et}, \mathrm{R}^{2}=\right.$ $\mathrm{CHPh}_{2}$ Co3, $\mathrm{R}^{1}=i$-Pr, $\mathrm{R}^{2}=\mathrm{CHPh}_{2}$ Co4, $\mathrm{R}^{1}=\mathrm{Cl}, \mathrm{R}^{2}=\mathrm{CHPh}_{2}$ Co5, $\mathrm{R}^{1}=\mathrm{CHPh}_{2}, \mathrm{R}^{2}=i$-Pr Co6, $\mathrm{R}^{1}=\mathrm{CHPh}_{2}, \mathrm{R}^{2}=t$-Bu Co7, $\left.\mathrm{R}^{1}=\mathrm{CHPh}_{2}, \mathrm{R}^{2}=\mathrm{F} \mathbf{C o 8}\right)$, have been prepared by a one-pot template approach. The molecular structures of Co1, Co6 and Co8 highlight the varying degrees of steric protection of the metal center imposed by the ortho-benzhydryl/- $\mathrm{R}^{1}$ group pairing. On activation with either MAO or MMAO, Co1 - Co5 collectively displayed high activity (up to $2.87 \times 10^{6} \mathrm{~g}$ (PE) $\mathrm{mol}^{-1}(\mathrm{Co}) \mathrm{h}^{-1}$ at $\left.40{ }^{\circ} \mathrm{C}\right)$ affording highly linear low molecular weight polyethylene $\left(M_{\mathrm{w}}\right.$ range: 12.8 - $\left.59.4 \mathrm{~kg} \mathrm{~mol}^{-1}\right)$ with narrow polydispersities $\left(M_{\mathrm{w}} / M_{\mathrm{n}}\right.$ range: $\left.1.4-2.7\right)$. End-group analysis of the polymers highlights the importance of both $\beta-\mathrm{H}$ elimination and chain transfer to aluminum as termination pathways. In relative terms, MMAO proved a marginally more effective activator than MAO with the catalytic activity, in either case, falling in the order: $\mathbf{C o 1}>\mathbf{C o 5}>$ Co2 $>$ Co3 $>$ Co4. In marked contrast, the 2,6-( $\left(\mathrm{CHPh}_{2}\right)_{2}$-substituted precatalysts, Co6, $\mathbf{C o} 7$ and Co8 gave, in the presence of same aluminoxane activators, only trace amounts of polyethylene.
\end{abstract}

Keywords: Cobalt; coordination-insertion polymerization; linear polyethylene; $\beta-\mathrm{H}$ elimination; catalytic activity. 


\section{Introduction}

Ever since the first disclosures of highly active homogeneous iron and cobalt catalysts for ethylene polymerization some twenty years ago, there has been a considerable drive to not only improve the performance characteristics of the catalyst but also broaden the range of polyolefinic materials. ${ }^{1,2}$ In terms of ligand support, the bis(imino)pyridine family has provided the benchmark framework that, through structural modification, allows control of both the catalyst activity and molecular weight of the polymer (A, Chart 1). ${ }^{3-21}$ Elsewhere, alternative $N, N, N$ ligand sets have also emerged as compatible supports for both iron and cobalt catalysts such as 2,9-bis(imino)1,10-phenanthrolines, ${ }^{22-27}$ 2-benzimidazol-6-imino-pyridines, ${ }^{28-31} N$-((pyridin-2-yl)methylene)-8iminoquinolines $^{32}$ and 2,8-bis(imino)quinolines. ${ }^{33}$ As a general feature to all these classes of catalyst is the ability to control the polymerization performance through the substitution pattern of the imine $N$-aryl groups. Specifically, sterically bulky groups at the ortho-positions promote chain propagation and activity while the electronic properties of the para-group can have some influence on catalytic activity. ${ }^{12-13,16-17}$

More recent developments have seen the emergence of ring-strain adjustable cycloalkylfused bis(imino)pyridines that allow an additional means of modulating activity and polymer molecular weight of not only iron and cobalt catalysts but also chromium (B - E, Chart 1). ${ }^{34-47}$ With particular regard to cobalt catalysts, the cyclohexyl-containing $\mathbf{B}^{35}$ shows reasonable activity generating highly linear polyethylene waxes and oligomers. On the other hand, cycloheptyl-C (Ar $=$ 2,6- $\mathrm{Me}_{2} \mathrm{Ph}, \quad 2,6-\mathrm{Et}_{2} \mathrm{Ph}, \quad 2,6-i-\mathrm{Pr}_{2} \mathrm{Ph}, 2,4,6-\mathrm{Me}_{2} \mathrm{Ph}, \quad 2,6-\mathrm{Et}_{2}-4-\mathrm{MePh}$ ), are generally more productive and afford solely low molecular weight polyethylene. ${ }^{41}$ With regard to the largest ring system $\mathbf{D},{ }^{45}$ high activity is again exhibited while the polyethylenes attain the highest molecular weight for the B - D series forming strictly linear polymer chains.

Within a fused ring family, further modulation of the molecular weight can be achieved by varying the steric properties of the $\mathrm{N}$-aryl ortho-substituents. For example, for the cycloheptylcontaining cobalt complexes, $\mathbf{C}$, the most sterically encumbered example $(\mathrm{Ar}=2,6-i-\mathrm{Pr} 2 \mathrm{Ph})$ forms 
the highest molecular weight polymer of this class. By comparison, cobalt precatalysts $\mathbf{E}$ (Chart 1), ${ }^{46}$ incorporating even more bulky ortho-cycloalkyl substituents, generate even higher molecular weight polyethylene of narrow dispersity. Conversely, the cycloheptyl-fused F-type complexes (Chart 1) bearing $N, N, O$-ligands, serve as precatalysts for ethylene oligomerization with good $\alpha$ olefin selectivity. ${ }^{48}$

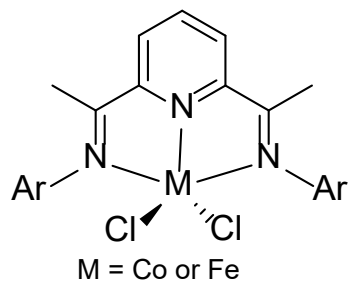

A

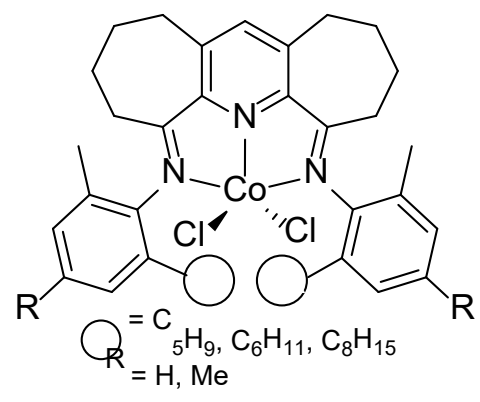

E

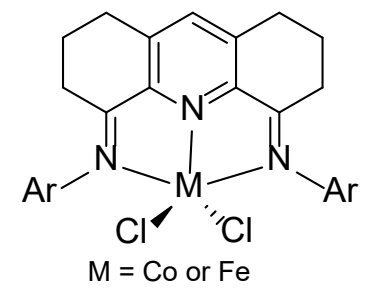

B

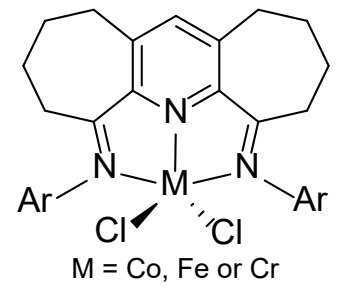

C

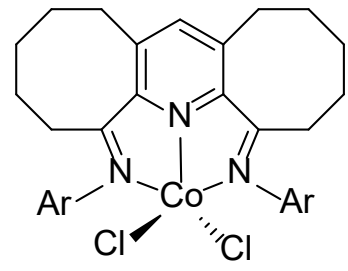

D

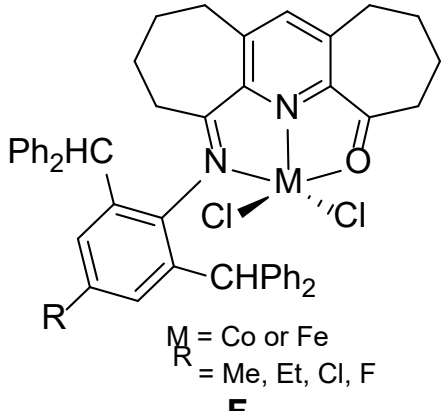

$\mathbf{F}$

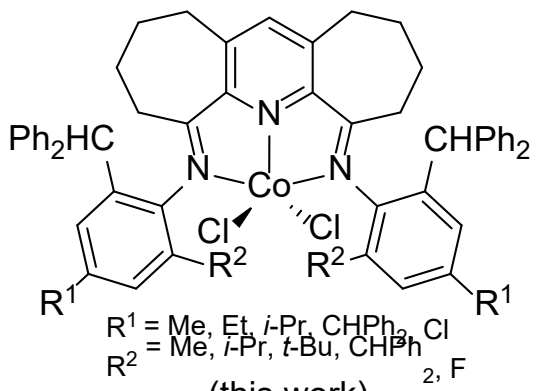

$\mathbf{G}^{\text {(this work) }}$

Chart 1 Fused-cycloalkyl $N, N, N$ - and $N, N, O$-complexes derived from A

In this work, we return to the bis(imino)-2,3:5,6-bis(pentamethylene)pyridine family of cobalt precatalysts ( $\mathbf{C}$ or $\mathbf{E}$, Chart 1) with a view to explore the effects of benzhydryl $\left(\mathrm{CHPh}_{2}\right)$ substitution on catalytic performance in ethylene polymerization. Indeed, incorporation of such sterically enhanced alkyl groups have been reported to impart some notable beneficial effects in related $N, N, N$-catalysts, including on catalyst activity, molecular weight and thermal stability. ${ }^{10,46}$ In particular, we describe the synthesis, characterization and catalytic evaluation (using two different co-catalysts) of a series of cobalt complexes of type $\mathbf{G}$ (Chart 1), in which at least one ortho-site of each $\mathrm{N}$-aryl group is appended by a $\mathrm{CHPh}_{2}$ group. In addition, the effect of introducing chloride, smaller alkyl groups $\left(\mathrm{R}^{1}=\mathrm{Me}, \mathrm{Et}, i\right.$-Pr) and $\mathrm{CHPh}_{2}$ at the remaining orthoposition is explored, while the para-position is the subject of an electronic investigation $\left(\mathrm{R}^{2}=\mathrm{Me}\right.$, $i$-Pr, $t$-Bu, $\left.\mathrm{CHPh}_{2}, \mathrm{~F}\right)$. 


\section{Experimental section}

\section{General considerations}

All manipulations involving air- and moisture-sensitive compounds were carried out under nitrogen atmosphere using standard Schlenk techniques. Toluene was refluxed over sodium and distilled under nitrogen prior to use. Methylaluminoxane (MAO, 1.46 M solution in toluene) and modified methylaluminoxane (MMAO, 1.93 M in n-heptane) were purchased from Akzo Nobel Corp. High-purity ethylene was purchased from Beijing Yansan Petrochemical Co. and used as received. Other reagents were purchased from Aldrich, Acros or local suppliers. FT-IR spectra were recorded on a Perkin-Elmer System 2000 FT-IR spectrometer. Elemental analysis was carried out using a Flash EA 1112 micro-analyzer. Molecular weights and molecular weight distributions $\left(M_{\mathrm{w}} / M_{\mathrm{n}}\right)$ of the polyethylenes were determined by Gel Permeation Chromatography using a PL-GPC220 instrument at $150{ }^{\circ} \mathrm{C}$ with 1,2,4-trichlorobenzene as the solvent. The thermograms for the crystallization and melt process of the polymers were recorded using a differential scanning calorimeter (DSC, TA-Q2000) under a nitrogen atmosphere. Typically, a sample of about $5.0 \mathrm{mg}$ was heated to $140{ }^{\circ} \mathrm{C}$ at a rate of $20{ }^{\circ} \mathrm{C} / \mathrm{min}$ and kept for $2 \mathrm{~min}$ at $140{ }^{\circ} \mathrm{C}$ to remove the thermal history and then cooled at a rate of $20{ }^{\circ} \mathrm{C} / \mathrm{min}$ to $-40{ }^{\circ} \mathrm{C}$. The ${ }^{13} \mathrm{C}$ NMR spectra of the polyethylenes were recorded on a Bruker DMX $300 \mathrm{MHz}$ instrument at $135^{\circ} \mathrm{C}$ in deuterated 1,1,2,2-tetrachloroethane- $d_{2}$ with TMS as an internal standard; $\delta$ values are given in ppm and $J$ values in Hz. The compounds, $\alpha, \alpha^{\prime}$-dioxo-2,3:5,6-bis(pentamethylene)pyridine, ${ }^{41,49-50}$ 2,4-dimethyl-6-benzhydrylaniline, 2-methyl-4,6-dibenzhydrylaniline, 2-ethyl-4,6dibenzhydrylaniline, 2-isopropyl-4,6-dibenzhydrylaniline, 2-chloro-4,6-dibenzhydrylaniline, 2,6dibenzhydryl-4-isopropylaniline, 2,6-dibenzhydryl-4-tertbutylaniline and 2,6-dibenzhydryl-4fluoroaniline were prepared using literature procedures. ${ }^{51-52}$ 


\section{Preparation of $\left[2,3: 5,6-\left\{\mathrm{C}_{4} \mathrm{H}_{8} \mathrm{C}\left(\mathrm{N}\left(2-\mathrm{R}^{1}-4-\mathrm{R}^{2}-6-\left(\mathrm{CHPh}_{2}\right) \mathrm{C}_{6} \mathrm{H}_{2}\right)\right)\right\}_{2} \mathrm{C}_{5} \mathrm{HN}\right] \mathrm{CoCl}_{2}$}

(a) $\mathrm{R}^{1}=\mathrm{R}^{2}=$ Me Co1. A mixture of $\alpha, \alpha^{\prime}$-dioxo-2,3:5,6-bis(pentamethylene)pyridine (0.243 g, 1.0 mmol), 2,4-dimethyl-6-benzhydrylaniline (1.15 g, $4.0 \mathrm{mmol})$ and $\mathrm{CoCl}_{2}(0.13 \mathrm{~g}, 1.0 \mathrm{mmol})$ in glacial acetic acid $(10 \mathrm{ml})$ was stirred and heated to reflux for $6 \mathrm{~h}$. Once cooled to room temperature, diethyl ether $(30 \mathrm{~mL})$ was added to precipitate a solid which was filtered and collected. This solid was then re-dissolved in methanol (40-50 mL) and the solution concentrated to a minimum volume (ca. $5 \mathrm{~mL}$ ). Diethyl ether was added again to induce precipitation and the resulting solid collected by filtration and dried under reduced pressure to give $\mathbf{C o 1}$ as a light green powder (0.48 g, 58\%). FT-IR (KBr, cm $\left.{ }^{-1}\right): 2938(\mathrm{w}), 2867(\mathrm{w}), 1599(v(\mathrm{C}=\mathrm{N}), \mathrm{s}), 1549(\mathrm{w}), 1492$ (s), 1449 (s), 1336 (m), 1257 (s), 1211 (m), 1152 (m), 1077 (m), $1031(\mathrm{~m}), 967$ (w), 783 (w), 747 (w), 701 (s). Anal. calc. for $\mathrm{C}_{57} \mathrm{H}_{55} \mathrm{Cl}_{2} \mathrm{CoN}_{3}$ (911.9): C, 75.08; H, 6.08; N, 4.61. Found: C, 75.06; $\mathrm{H}, 6.07 ; \mathrm{N}, 4.60 \%$.

(b) $\mathrm{R}^{1}=\mathrm{Me}, \mathrm{R}^{2}=\mathrm{CHPh}_{2} \mathbf{C o 2}$. Using a similar procedure and molar ratios to that described for

Co1 but with 2-methyl-4,6-dibenzhydrylaniline as the amine, Co2 was obtained as a light green powder (0.49 g, 40\%). FT-IR (KBr, cm $\left.{ }^{-1}\right): 2936(\mathrm{w}), 2866(\mathrm{w}), 1598(v(\mathrm{C}=\mathrm{N}), \mathrm{s}), 1552(\mathrm{w}), 1493$ (s), 1448 (s), $1341(\mathrm{w}), 1258(\mathrm{~s}), 1208(\mathrm{~m}), 1151(\mathrm{~m}), 1077$ (m), $1031(\mathrm{~m}), 1003(\mathrm{w}), 967$ (m), 850 (w), 818 (w), 741 (w), 697 (s).Anal. calc. for $\mathrm{C}_{81} \mathrm{H}_{71} \mathrm{Cl}_{2} \mathrm{CoN}_{3}$ (1216.3): C, 79.99; H, 5.88; N, 3.45. Found: C, 79.97; H, 5.88; N, 3.44\%.

(c) $\mathrm{R}^{1}=\mathrm{Et}, \mathrm{R}^{2}=\mathrm{CHPh}_{2} \mathbf{C o 3}$. Using a similar procedure and molar ratios to that described for $\mathbf{C o 1}$ but with 2-ethyl-4,6-dibenzhydrylaniline as the amine, Co3 was obtained as a light green powder (0.49 g, 40\%). FT-IR (KBr, cm $\left.{ }^{-1}\right): 2970(\mathrm{w}), 2873(\mathrm{w}), 1630(\mathrm{~m}), 1600(v(\mathrm{C}=\mathrm{N}), \mathrm{s}), 1576(\mathrm{w})$, $1551(\mathrm{w}), 1490(\mathrm{~m}), 1449$ (s), $1378(\mathrm{w}), 1283(\mathrm{w}), 1255(\mathrm{~m}), 1203(\mathrm{~m}), 1172(\mathrm{w}), 1145(\mathrm{w}), 1075$ (w), $1039(\mathrm{w}), 1006(\mathrm{w}), 974(\mathrm{w}), 922(\mathrm{w}), 897(\mathrm{w}), 861(\mathrm{w}), 742(\mathrm{w}), 698(\mathrm{~s}) \mathrm{cm}^{-1}$. Anal. calc. for $\mathrm{C}_{83} \mathrm{H}_{75} \mathrm{Cl}_{2} \mathrm{CoN}_{3}$ (1244.37): C, 80.11; H, 6.08; N, 3.38. Found: C, 79.8; H, 5.88; N, 3.49\%. 
(d) $\mathrm{R}^{1}=i$-Pr, $\mathrm{R}^{2}=\mathrm{CHPh}_{2}$ Co4. Using a similar procedure and molar ratios to that described for

Co1 but with 2-iso-propyl-4,6-dibenzhydrylaniline as the amine, Co4 was obtained as a light green powder $(0.49 \mathrm{~g}, 30 \%)$. FT-IR $\left(\mathrm{KBr}, \mathrm{cm}^{-1}\right)$ : $2934(\mathrm{w}), 2866(\mathrm{w}), 1598(v(\mathrm{C}=\mathrm{N}), \mathrm{s}), 1553(\mathrm{w})$, 1493 (s), 1447 (s), 1339 (m), 1255 (s), 1208 (m), 1149 (m), 1076 (m), 1032 (m), 966 (w), 913 (m), 856 (w), 776 (w), 743 (w), 698 (s). Anal. calc. for $\mathrm{C}_{85} \mathrm{H}_{79} \mathrm{Cl}_{2} \mathrm{CoN}_{3}$ (1272.42): C, 80.24; H, 6.26; N, 3.30. Found: C, 79.80; H, 6.00; N, 3.38\%.

(e) $\mathrm{R}^{1}=\mathrm{Cl}, \mathrm{R}^{2}=\mathrm{CHPh}_{2} \mathbf{C o 5}$. Using a similar procedure and molar ratios to that described for Co1 but with 2-chloro-4,6-dibenzhydrylaniline as the amine, Co5 was obtained as a light green powder (0.423 g, 38\%). FT-IR (KBr, cm $\left.{ }^{-1}\right): 2935(\mathrm{w}), 2870(\mathrm{w}), 1598(v(\mathrm{C}=\mathrm{N}), \mathrm{s}), 1556(\mathrm{w}), 1494(\mathrm{~s})$, 1448 (s), 1339 (m), 1256 (s), 1224 (m), 1170 (m), 1077 (m), 1030 (m), 965 (w), 924 (m), 888 (w), 794 (w), 765 (w), 698 (s). Anal. calc. for $\mathrm{C}_{79} \mathrm{H}_{65} \mathrm{Cl}_{4} \mathrm{CoN}_{3}$ (1257.1): C, 75.48; H, 5.21; N, 3.34 . Found: C, 75.65; H, 5.15; N, 3.34\%.

(f) $\mathrm{R}^{1}=\mathrm{CHPh}_{2}, \mathrm{R}^{2}=i$-Pr Co6. Using a similar procedure and molar ratios to that described for Co1 but with 2,6-dibenzhydryl-4-isopropylaniline as the amine, Co6 was obtained as a light green powder (0.665 g, 52\%). FT-IR (KBr, cm $\left.{ }^{-1}\right): 2951(\mathrm{w}), 2866(\mathrm{w}), 1594(v(\mathrm{C}=\mathrm{N}), \mathrm{s}), 1548(\mathrm{w}), 1493$ (s), 1447 (s), $1340(\mathrm{~m}), 1255$ (s), $1210(\mathrm{~m}), 1172(\mathrm{~m}), 1076(\mathrm{~m}), 1031(\mathrm{~m}), 964(\mathrm{w}), 930(\mathrm{~m}), 862$ (w), 794 (w), 765 (w), 698 (s). Anal. calc. for $\mathrm{C}_{85} \mathrm{H}_{79} \mathrm{Cl}_{2} \mathrm{CoN}_{3}$ (1272.4): C, 80.24; H, 6.26; N, 3.30 . Found: C, 80.06; H, 6.25; N, 3.30\%.

(g) $\mathrm{R}^{1}=\mathrm{CHPh}_{2}, \mathrm{R}^{2}=t$-Bu Co7. Using a similar procedure and molar ratios to that described for Co1 but with 2,6-dibenzhydryl-4-tert-butyl aniline as the amine, Co7 was obtained as a light green powder (0.533 g, 41\%). FT-IR: $2948(\mathrm{w}), 2868(\mathrm{w}), 1595(v(\mathrm{C}=\mathrm{N}), \mathrm{s}), 1544(\mathrm{w}), 1491(\mathrm{~s})$, 1449 (s), 1337 (m), 1257 (s), 1210 (m), 1184 (m), 1078 (m), 1030 (m), 933 (m), 893 (m), 823 (m), 770 (m), 743 (m), 698 (s). Anal. calc. for $\mathrm{C}_{87} \mathrm{H}_{83} \mathrm{Cl}_{2} \mathrm{CoN}_{3}$ (1300.5): C 80.35, H 6.43, N 3.23. Found C 80.00, H 6.41, N 3.20\%. 
(h) $\mathrm{R}^{1}=\mathrm{CHPh}_{2}, \mathrm{R}^{2}=\mathrm{F} \mathbf{C o 8}$. Using a similar procedure and molar ratios to that described for Co1 but with 2,6-dibenzhydryl-4-fluorophenyl aniline as the amine, $\mathbf{C o 8}$ was obtained as a light green powder (0.489 g, 40\%). FT-IR: $2946(\mathrm{w}), 2869(\mathrm{w}), 1593(v(\mathrm{C}=\mathrm{N}), \mathrm{s}), 1545(\mathrm{w}), 1494(\mathrm{~s}), 1444$ (s), 1345 (m), 1260 (m), 1183 (s), 1158 (m), 1077 (m), 1030 (m), $969(\mathrm{w}), 935(\mathrm{~m}), 865(\mathrm{w}), 790$ (w), 765 (w), 699 (s). Anal. calc. for $\mathrm{C}_{79} \mathrm{H}_{65} \mathrm{Cl}_{2} \mathrm{CoF}_{2} \mathrm{~N}_{3}$ (1224.22): C, 77.51; H, 5.35; N, 3.43 . Found: C, 77.45; H, 5.31; N, 3.45\%.

\section{Ethylene polymerization at 5/10 atm ethylene pressure}

The autoclave was evacuated and backfilled with ethylene three times. When the required temperature was reached, the precatalyst $(5 \mu \mathrm{mol})$ was dissolved in toluene $(30 \mathrm{~mL})$ in a Schlenk tube and injected into the autoclave containing ethylene ( $\mathrm{ca} .1 \mathrm{~atm})$ followed by the addition of more toluene $(30 \mathrm{~mL})$. The required amount of co-catalyst (MAO and MMAO) and additional toluene were added successively by syringe taking the total volume of toluene to $100 \mathrm{~mL}$. The autoclave was immediately pressurized with $5 / 10$ atm. pressure of ethylene and the stirring commenced. After the required reaction time, the reactor was cooled with a water bath and the excess ethylene vented. Following quenching of the reaction with $10 \%$ hydrochloric acid in ethanol, the polymer was collected and washed with ethanol and dried under reduced pressure at $50{ }^{\circ} \mathrm{C}$ and weighed.

\section{Ethylene polymerization at 1 atm ethylene pressure}

The polymerization at 1 atm ethylene pressure was carried out in a Schlenk tube. Under an ethylene atmosphere (1 atm), Co1 $(5 \mu \mathrm{mol})$ was added followed by toluene $(30 \mathrm{~mL})$ and then the required amount of co-catalyst (MAO, MMAO) introduced by syringe. The solution was then stirred at $30{ }^{\circ} \mathrm{C}$ under an ethylene atmosphere $(1 \mathrm{~atm})$. After $30 \mathrm{~min}$, the solution was quenched with $10 \%$ hydrochloric acid in ethanol. The polymer was washed with ethanol, dried under reduced pressure at $40{ }^{\circ} \mathrm{C}$ and then weighed.

\section{X-ray Crystallographic Studies}


The single-crystal X-ray diffraction studies of Co1, Co6 and Co8 were carried out on a Rigaku sealed Tube CCD (Saturn 724+) diffractometer with graphite-monochromated Mo-K $\alpha$ radiation $(\lambda=0.71073 \AA)$ at $173(2) \mathrm{K}$; cell parameters were obtained by global refinement of the positions of all collected reflections. Intensities were corrected for Lorentz and polarization effects and empirical absorption. The structures were solved by direct methods and refined by full-matrix least squares on $F^{2}$. All non-hydrogen atoms were placed in calculated positions. Structural solution and refinement were performed by using the SHELXTL-97 package. ${ }^{53-54}$ The free solvents present within the single crystal were removed by using the SQUEEZE option of the crystallographic program PLATON. ${ }^{53-54}$ Details of the X-ray refinements are provided in Table1.

Table 1. Crystal data and structure refinement for Co1, Co6 and Co8

\begin{tabular}{|c|c|c|c|}
\hline & Co1 & Co6 & $\mathrm{Co8}$ \\
\hline CCDC No. & 1854922 & 1854923 & 1854924 \\
\hline Empirical formula & $\mathrm{C}_{57} \mathrm{H}_{55} \mathrm{Cl}_{2} \mathrm{CoN}_{3}$ & $\mathrm{C}_{85} \mathrm{H}_{79} \mathrm{Cl}_{2} \mathrm{CoN}_{3}$ & $\mathrm{C}_{79} \mathrm{H}_{65} \mathrm{Cl}_{2} \mathrm{CoF}_{2} \mathrm{~N}_{3}$ \\
\hline $\mathrm{F}_{\mathrm{w}}$ & 911.87 & 1272.43 & 1224.17 \\
\hline $\mathrm{T}(\mathrm{K})$ & $173.15(2)$ & 173.15 & $293.00(2)$ \\
\hline Wavelength & 0.71073 & 0.71073 & 0.71073 \\
\hline Crystal system & Monoclinic & Monoclinic & Monoclinic \\
\hline Space group & $\mathrm{P} 2_{1} / \mathrm{c}$ & $\mathrm{P} 2_{1} / \mathrm{c}$ & $\mathrm{P} 2_{1} / \mathrm{c}$ \\
\hline $\mathrm{a}(\AA)$ & $10.2828(4)$ & $24.108(5)$ & $10.599(2)$ \\
\hline $\mathrm{b}(\AA)$ & $26.5515(6)$ & $15.504(3)$ & $27.076(5)$ \\
\hline $\mathrm{c}(\AA)$ & $19.0766(7)$ & $20.334(4)$ & $23.589(5)$ \\
\hline$\alpha\left(^{\circ}\right)$ & 90.00 & 90.00 & 90.00 \\
\hline$\beta\left(^{\circ}\right)$ & $104.488(4)$ & $93.60(3)$ & $101.95(3)$ \\
\hline$\gamma\left({ }^{\circ}\right)$ & 90.00 & 90.00 & 90.00 \\
\hline $\mathrm{V}\left(\AA^{3}\right)$ & $5042.7(3)$ & $7585(3)$ & $6623(2)$ \\
\hline Z & 4 & 4 & 4 \\
\hline $\mathrm{D}_{\text {calcd }}\left(\mathrm{mg} \mathrm{m}^{3}\right)$ & 1.201 & 1.114 & 1.228 \\
\hline$\mu\left(\mathrm{mm}^{-1}\right)$ & 0.485 & 0.340 & 0.391 \\
\hline $\mathrm{F}(000)$ & 1916.0 & 2687.3 & 2556.0 \\
\hline \multirow[t]{2}{*}{ Crystal size (mm) } & $0.213 \times 0.064 \times$ & $0.137 \times 0.094 \times$ & $0.421 \times 0.105 \times$ \\
\hline & 0.043 & 0.053 & 0.087 \\
\hline$\theta$ range $\left(^{\circ}\right)$ & $3.068-63.162$ & $1.7-54.96$ & $1.159-27.489$ \\
\hline \multirow[t]{3}{*}{ Limiting indices } & $-14<=\mathrm{h}<=14$ & $-30<=\mathrm{h}<=31$ & $-13<=\mathrm{h}<=13$ \\
\hline & $-36<=\mathrm{k}<=36$ & $-20<=\mathrm{k}<=20$ & $-35<=\mathrm{k}<=35$ \\
\hline & $-26<=1<=27$ & $-25<=1<=26$ & $-30<=1<=30$ \\
\hline No. of rflns collected & 84680 & 80235 & 77296 \\
\hline No. unique rflns [R(int)] & $15695(0.0903)$ & $17362(0.1018)$ & $15123(0.0572)$ \\
\hline Completeness to $\theta(\%)$ & $93 \%$ & $100 \%$ & $99.6 \%$ \\
\hline Data/restraints/params & 15695 / 211 / 627 & 17362 / 0 / 823 & $15123 / 468 / 940$ \\
\hline
\end{tabular}




\begin{tabular}{llll}
\hline Goodness of fit on $F^{2}$ & 1.061 & 1.022 & 1.191 \\
Final $\mathrm{R}$ indexes $[\mathrm{I}>=2 \sigma(\mathrm{I})]$ & $\mathrm{R}_{1}=0.0954$, & $\mathrm{R}_{1}=0.1649$, & $\mathrm{R}_{1}=0.0805$ \\
& $\mathrm{wR}_{2}=0.2062$ & $\mathrm{wR}_{2}=0.2616$ & $\mathrm{wR}_{2}=0.1840$ \\
& $\mathrm{R}_{1}=0.1736$, & $\mathrm{R}_{1}=0.1935$ & $\mathrm{R}_{1}=0.0865$ \\
& $\mathrm{wR}_{2}=0.2386$ & $\mathrm{wR}_{2}=0.2779$ & $\mathrm{wR}_{2}=0.1883$ \\
Largest diff peak and hole $\left(\mathrm{e} \AA^{-3}\right)$ & 0.89 and -0.79 & 1.41 and -1.20 & 0.429 and -0.411 \\
\hline
\end{tabular}

\section{Results and discussion}

Condensation of diketone $\alpha, \alpha^{\prime}$-dioxo-2,3:5,6-bis(pentamethylene)pyridine with two equivalents of 2-( $\left(\mathrm{CHPh}_{2}\right)-4-\mathrm{R}^{1}-6-\mathrm{R}^{2} \mathrm{C}_{6} \mathrm{H}_{2} \mathrm{NH}_{2}\left(\mathrm{R}^{1}=\mathrm{Me}, \mathrm{R}^{2}=\mathrm{Me} ; \mathrm{R}^{1}=\mathrm{Me}, \mathrm{R}^{2}=\mathrm{CHPh}_{2} ; \mathrm{R}^{1}=\mathrm{Et}, \mathrm{R}^{2}=\mathrm{CHPh}_{2} ;\right.$ $\mathrm{R}^{1}=i-\operatorname{Pr}, \mathrm{R}^{2}=\mathrm{CHPh}_{2} ; \mathrm{R}^{1}=\mathrm{Cl}, \mathrm{R}^{2}=\mathrm{CHPh}_{2} ; \mathrm{R}^{1}=\mathrm{CHPh}_{2}, \mathrm{R}^{2}=i-\mathrm{Pr} ; \mathrm{R}^{1}=\mathrm{CHPh}_{2}, \mathrm{R}^{2}=t-\mathrm{Bu} ; \mathrm{R}^{1}=$ $\left.\mathrm{CHPh}_{2}, \mathrm{R}^{2}=\mathrm{F}\right)$ in the presence of cobalt chloride gave, on work-up, $\left[2,3: 5,6-\left\{\mathrm{C}_{4} \mathrm{H}_{8} \mathrm{C}\left(\mathrm{N}\left(2-\mathrm{R}^{1}-4-\right.\right.\right.\right.$ $\left.\left.\left.\left.\mathrm{R}^{2}-6-\left(\mathrm{CHPh}_{2}\right) \mathrm{C}_{6} \mathrm{H}_{2}\right)\right)\right\}_{2} \mathrm{C}_{5} \mathrm{HN}\right] \mathrm{CoCl}_{2}\left(\mathrm{R}^{1}=\mathrm{R}^{2}=\mathrm{Me} \mathrm{Co1}, \mathrm{R}^{1}=\mathrm{Me}, \mathrm{R}^{2}=\mathrm{CHPh}_{2} \mathbf{C o 2}, \mathrm{R}^{1}=\mathrm{Et}, \mathrm{R}^{2}=\right.$ $\mathrm{CHPh}_{2} \mathbf{C o 3}, \mathrm{R} 1=i-\mathrm{Pr}, \mathrm{R}^{2}=\mathrm{CHPh}_{2} \mathbf{C o 4}, \mathrm{R}^{1}=\mathrm{Cl}, \mathrm{R}^{2}=\mathrm{CHPh}_{2} \mathbf{C o 5}, \mathrm{R}^{1}=\mathrm{CHPh}_{2}, \mathrm{R}^{2}=i-\operatorname{Pr} \mathbf{C o 6}$, $\mathrm{R}^{1}=\mathrm{CHPh}_{2}, \mathrm{R}^{2}=t$-Bu Co7, $\left.\mathrm{R}^{1}=\mathrm{CHPh}_{2}, \mathrm{R}^{2}=\mathrm{F} \mathbf{C o 8}\right)$, in moderate yields (30 - 58\%) (Scheme 1). The free ligands did not prove amenable to isolation and so the above template approach was implemented to access the complexes in one step; similar one pot approaches have been employed elsewhere. ${ }^{35,40-44,48}$ All complexes are air and moisture stable and have been characterized by infrared spectroscopy and elemental analysis. In addition, crystals of Co1, Co6 and Co8 have been the subject of single crystal X-ray diffraction studies.

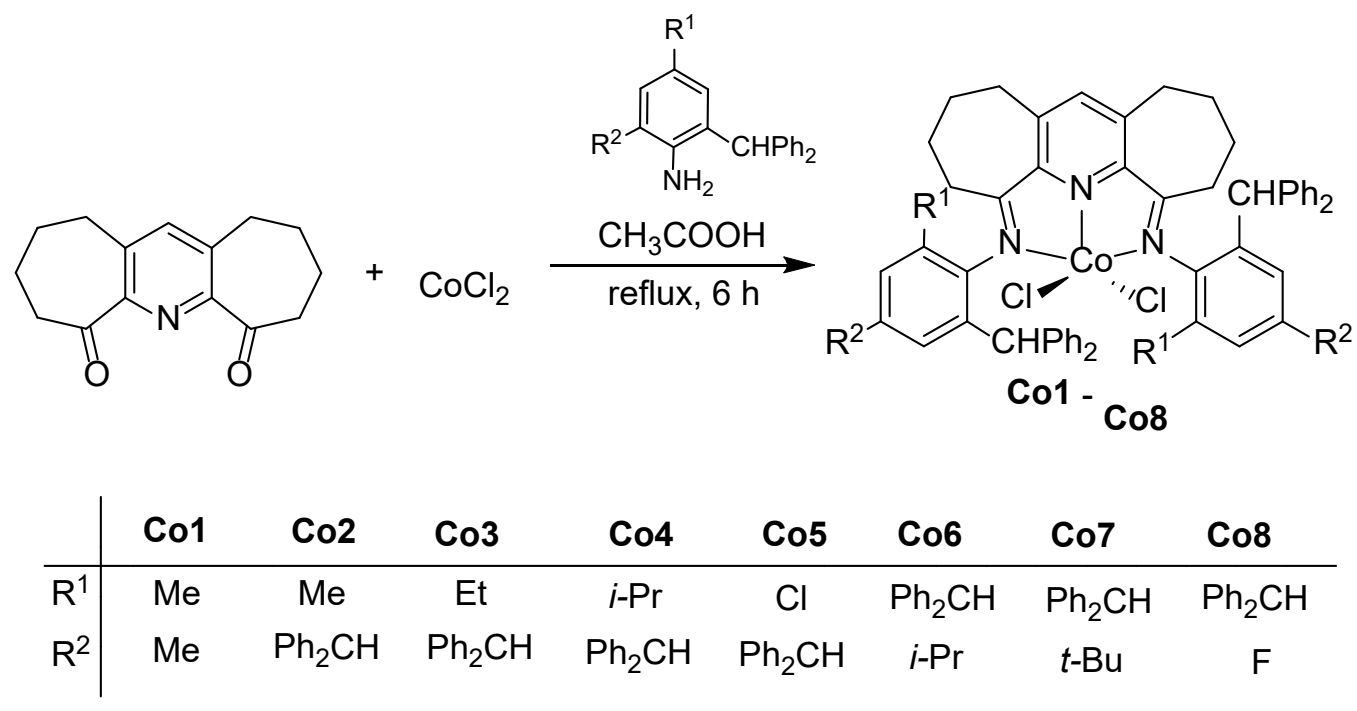

Scheme 1 One-pot template route to $\mathrm{Co1}$ - Co8 
Single crystals of Co1, Co6 and Co8 suitable for the X-ray determinations were grown by slow diffusion of diethyl ether into a dichloromethane solution of the corresponding complex at ambient temperature. Perspective views of the complexes are shown in Figures 1, 2 and 3; selected bond distances and angles for all three are collected in Table 1. All the structures are similar and will be discussed together. Each consists of a single cobalt center surrounded by the three nitrogen atoms belonging to the bis(arylimino)-2,3:5,6-bis(pentamethylene)pyridine (aryl = 2,4-Me -6 $\left.\left(\mathrm{CHPh}_{2}\right) \mathrm{C}_{6} \mathrm{H}_{2} \mathbf{C o 1}, 2,6-\left(\mathrm{CHPh}_{2}\right)_{2}-4-i-\mathrm{PrC}_{6} \mathrm{H}_{2} \mathbf{C o 6}, 2,6-\left(\mathrm{CHPh}_{2}\right)_{2}-4-\mathrm{FC}_{6} \mathrm{H}_{2} \mathbf{C o 8}\right)$ and two chlorides to complete a five-coordinate geometry best described as distorted square-pyramidal geometry. The three nitrogen and $\mathrm{Cl} 2$ atoms form the basal plane with $\mathrm{Cl} 1$ occupying the apical position, while the cobalt atoms lie at a distance of $0.497 \AA$ (Co1), $0.567 \AA$ (Co6) and $0.468 \AA$ (Co8) above this basal plane; similar arrangements have been found in previously reported analogues..$^{35,39,41,43,45-46,55-56}$ Of the three nitrogen donors within the tridentate ligand, the central pyridine nitrogen forms the shortest Co-N bond distance [2.044(3) $\AA$ Co1, 2.052(5) $\AA$ Co6, $2.070(2) \AA \mathbf{C o 8}]$ and indeed compares favorably with those found in $\mathbf{A}(2.051-2.056 \AA),{ }^{1-2,4,6} \mathbf{B}$ $(2.037 \AA),{ }^{35} \mathbf{C}(2.082 \AA)^{41} \mathbf{D}(2.072-2.079 \AA)^{45}, \mathbf{E}(2.087 \AA)^{46}$ and $\mathbf{F}(2.072-2.079 \AA) .{ }^{48}$ The

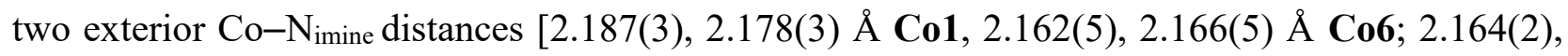
2.173(3) $\AA$ Co8] are similar, despite the more demanding 2,6-dibenzhydryl N-aryl substitution in Co6 and Co8. Within the two 5-membered chelate rings, the N2-Co1-N1 and N1-Co1-N3 bond angles are close in value $\left[75.96(12)^{\circ}, 75.30(12)^{\circ}\right.$ Co1; 74.9(2) ${ }^{\circ}, 74.9(2)^{\circ}$ Co6; 74.99(9) 74.66(10) ${ }^{\circ}$ Co8], N(2)-Co(1)-N(3) and comparable with related structures. ${ }^{35-37,39,41,43,45,47}$ The $\mathrm{N}(1)-\mathrm{C}(15)-\mathrm{C}(1)-\mathrm{N}(3)$ and $\mathrm{N}(2)-\mathrm{C}(13)-\mathrm{C}(14)-\mathrm{N}(1)$ torsion angles $\left[-13.83^{\circ},-17.05^{\circ}(\mathbf{C o 1})\right.$, $\left.3.63^{\circ}, 0.05^{\circ}(\mathbf{C o 6}),-6.82^{\circ}, 10.73^{\circ}(\mathbf{C o 8})\right]$ highlight the deviation from co-planarity between the pyridine ring and the neighboring imine vectors. As expected the saturated sections of the fused seven-membered rings, C2-C3-C4-C5 and C9-C10-C11-C12, adopt puckered configurations on account of the $\mathrm{sp}^{3}$-hybridized carbon atoms. For Co1 the N-aryl groups are inclined at an angle of $86.82^{\circ}$ av with respect to the imine vectors while in $\mathbf{C o 6}$ and $\mathbf{C o 8}$ the corresponding angles decrease 
to $82.14^{\circ}$ av and $78.3^{\circ}$ av, likely reflecting the presence of the more sterically demanding $2,6-$ benzhydryl substitution in $\mathbf{C o 6}$ and $\mathbf{C o 8}$. There are no intermolecular contacts of note.
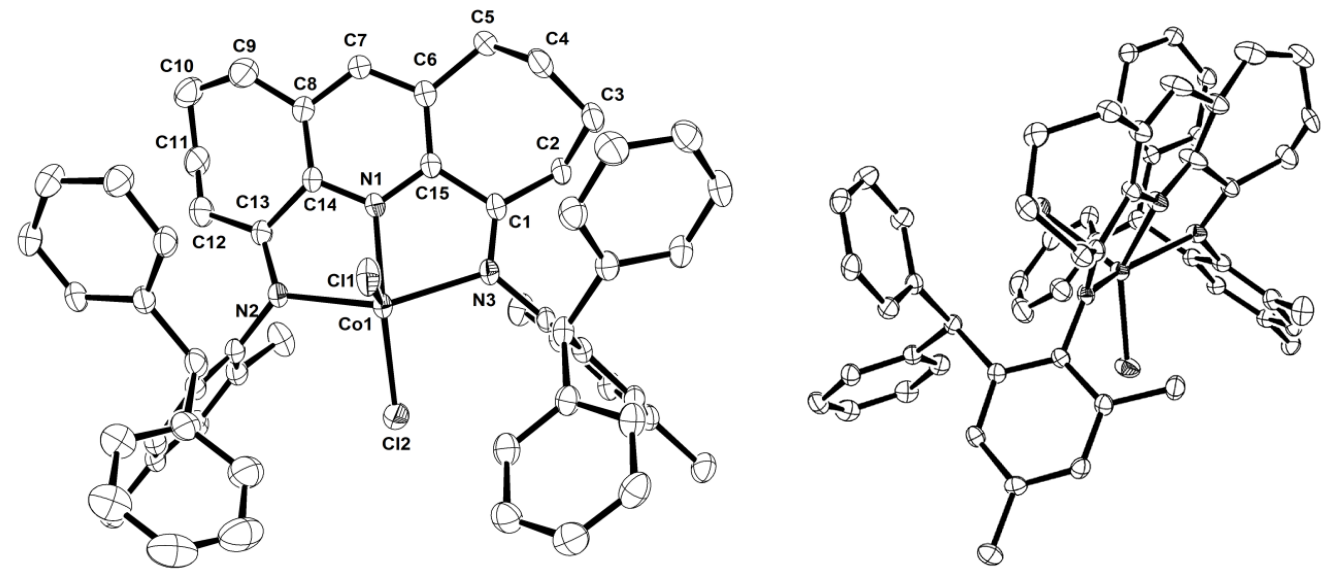

Figure 1 ORTEP representations of Co1. Thermal ellipsoids are shown at 30\% probability and hydrogen atoms have been omitted for clarity.
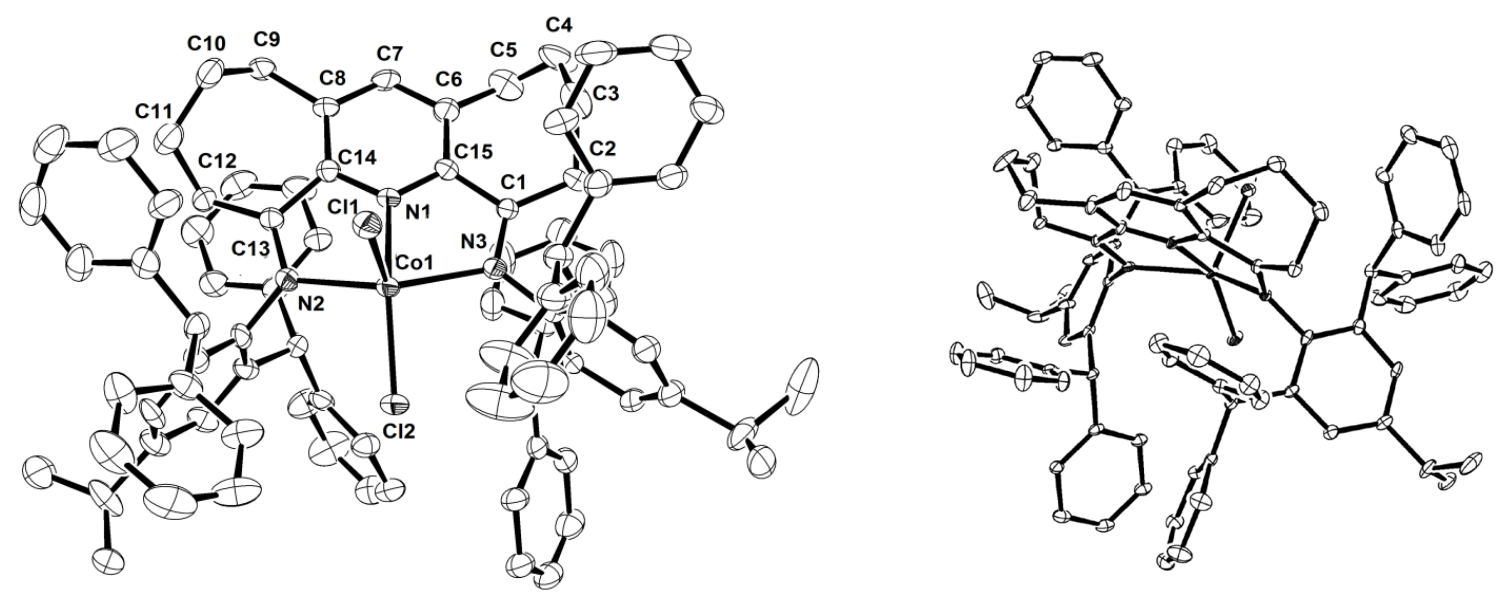

Figure 2 ORTEP representations of Co6. Thermal ellipsoids are shown at 30\% probability and the hydrogen atoms have been omitted for clarity.
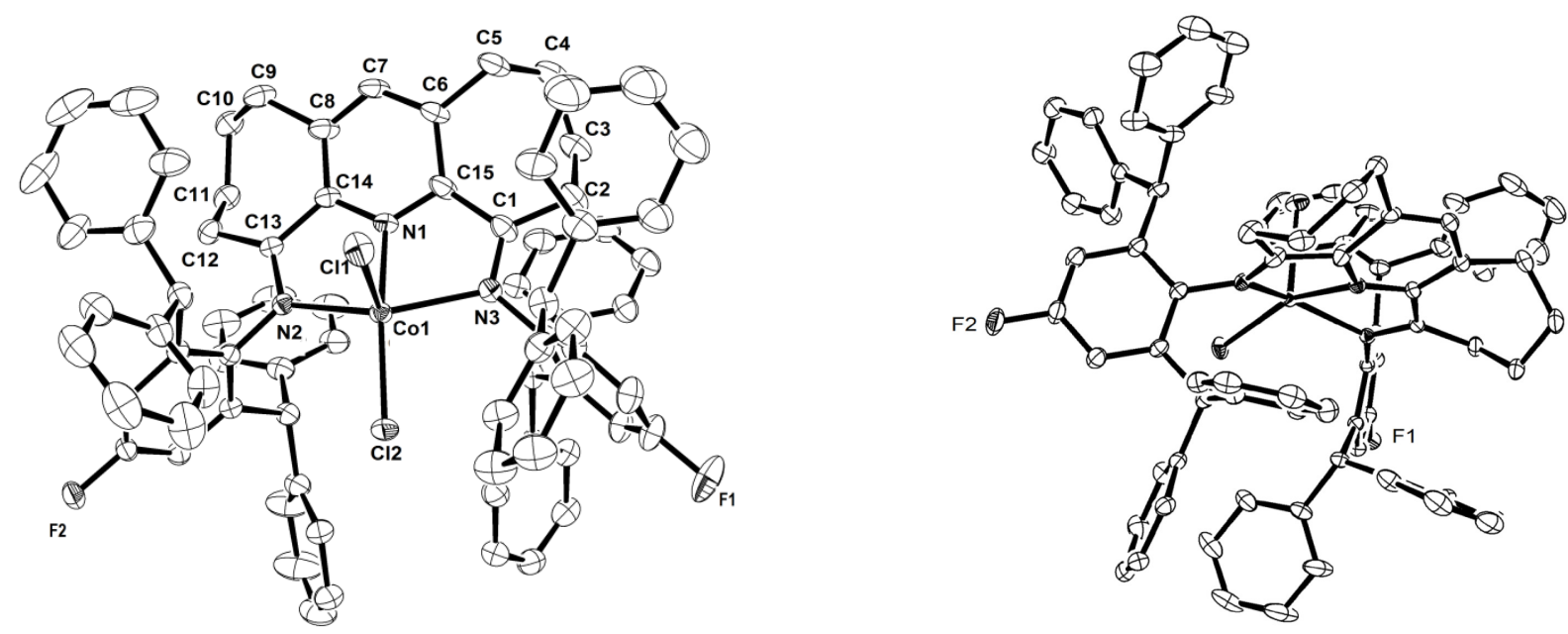

Figure 3 ORTEP representations of $\mathbf{C o 8}$. Thermal ellipsoids are shown at 30\% probability and the hydrogen atoms have been omitted for clarity. 
Table 2 Selected lengths $(\AA)$ and angles $\left(^{\circ}\right)$ for $\mathbf{C o 1}, \mathbf{C o 6}$ and $\mathbf{C o 8}$

\begin{tabular}{|l|l|l|l|}
\hline \multicolumn{5}{|c|}{ Co1 } & \multicolumn{1}{c|}{ Co6 } & \multicolumn{1}{c|}{ Co8 } \\
\hline \multicolumn{5}{|c|}{ Bond lengths $[\AA]$} \\
\hline $\mathrm{Co}(1)-\mathrm{N}(1)$ & $2.044(3)$ & $2.052(5)$ & $2.070(2)$ \\
\hline $\mathrm{Co}(1)-\mathrm{N}(2)$ & $2.187(3)$ & $2.162(5)$ & $2.164(2)$ \\
\hline $\mathrm{Co}(1)-\mathrm{Cl}(1)$ & $2.178(3)$ & $2.166(5)$ & $2.173(3)$ \\
\hline $\mathrm{Co}(1)-\mathrm{Cl}(2)$ & $2.2904(12)$ & $2.295(2)$ & $2.3128(11)$ \\
\hline $\mathrm{N}(3)-\mathrm{C}(1)$ & $2.2489(12)$ & $2.2595(18)$ & $2.2531(9)$ \\
\hline $\mathrm{N}(2)-\mathrm{C}(13)$ & $1.285(5)$ & $1.295(8)$ & $1.290(4)$ \\
\hline $\mathrm{N}(1)-\mathrm{C}(14)$ & $1.358(13)$ & $1.288(8)$ & $1.296(4)$ \\
\hline $\mathrm{N}(1)-\mathrm{C}(15)$ & $1.330(5)$ & $1.352(8)$ & $1.336(4)$ \\
\hline \multicolumn{5}{|c|}{ Bond angles $\left[{ }^{\circ}\right]$} & $1.336(4)$ \\
\hline $\mathrm{N}(2)-\mathrm{Co}(1)-\mathrm{N}(3)$ & $144.10(12)$ & $141.8(2)$ & $144.21(9)$ \\
\hline $\mathrm{N}(1)-\mathrm{Co}(1)-\mathrm{N}(3)$ & $75.30(12)$ & $74.9(2)$ & $74.66(10)$ \\
\hline $\mathrm{N}(2)-\mathrm{Co}(1)-\mathrm{N}(1)$ & $74.96(12)$ & $74.9(2)$ & $74.99(9)$ \\
\hline $\mathrm{N}(3)-\mathrm{Co}(1)-\mathrm{Cl}(1)$ & $99.34(8)$ & $104.88(14)$ & $98.52(7)$ \\
\hline $\mathrm{N}(3)-\mathrm{Co}(1)-\mathrm{Cl}(2)$ & $98.16(9)$ & $97.37(14)$ & $100.20(7)$ \\
\hline $\mathrm{N}(2)-\mathrm{Co}(1)-\mathrm{Cl}(1)$ & $92.97(11)$ & $98.79(15)$ & $100.68(7)$ \\
\hline $\mathrm{N}(2)-\mathrm{Co}(1)-\mathrm{Cl}(2)$ & $96.20(9)$ & $98.78(14)$ & $100.10(7)$ \\
\hline $\mathrm{Cl}(1)-\mathrm{Co}(1)-\mathrm{Cl}(2)$ & $115.72(8)$ & $112.10(4)$ & $119.52(5)$ \\
\hline $\mathrm{C}(1)-\mathrm{N}(3)-\mathrm{Co}(1)$ & $114.7(2)$ & $115.4(4)$ & $115.3(2)$ \\
\hline $\mathrm{C}(13)-\mathrm{N}(2)-\mathrm{Co}(1)$ & $116.4(5)$ & $114.3(4)$ & $115.7(2)$ \\
\hline
\end{tabular}

Further support for the structural composition of Co1 - Co8 was provided by the microanalytical and IR data, the latter revealing imine absorptions around $1600 \mathrm{~cm}^{-1}$ which are typical of cobalt(II)-coordinated imine nitrogens..$^{1,41,45}$

\section{Catalyst evaluation for ethylene polymerization}

To explore the performance of $\mathbf{C o 1}$ - Co8 in ethylene polymerization, two types of co-catalyst were selected for their activation namely methylaluminoxane (MAO) and modified methylaluminoxane (MMAO). Indeed, scrutiny of the literature reveals that these two aluminoxanes have proved the most suitable co-catalyst for activating related cobalt precatalysts. ${ }^{1-}$ 6,35-48 To determine the effectiveness of each, we initiated two separate studies to investigate the performance of the eight structurally distinct precatalysts. However, in both studies an optimization of the conditions was initially performed using Co1 as the test precatalyst. All polymeric material has been characterized by gel permeation chromatography (GPC), differential 
scanning calorimetry (DSC) and in selected cases by high temperature ${ }^{13} \mathrm{C}$ NMR spectroscopy; GC was also used to assess for the formation of any oligomeric products.

\section{Optimization of Co1/MAO for ethylene polymerization}

To allow an optimization of Co1/MAO as a catalyst for ethylene polymerization, the molar ratio of MAO to precatalyst $(\mathrm{Al} / \mathrm{Co})$, reaction temperature and run time were all systematically varied. Typically, the runs were performed in toluene under 10 atm $\mathrm{C}_{2} \mathrm{H}_{4}$. Firstly, the $\mathrm{Al} / \mathrm{Co}$ molar ratio was varied from 500 to 2500 with the temperature set at $30{ }^{\circ} \mathrm{C}$ and the polymerization run time at 30 minutes (entries $1-7$, Table 3$)$. A peak in activity of $1.31 \times 10^{6} \mathrm{~g}(\mathrm{PE}) \mathrm{mol}^{-1}(\mathrm{Co}) \mathrm{h}^{-1}$ was observed with an $\mathrm{Al} / \mathrm{Co}$ ratio of 1000 (entry 3, Table 3). As the ratio was increased above 1000, the catalytic activities steadily decreased reaching a minimum value of $0.92 \times 10^{6} \mathrm{~g}(\mathrm{PE}) \mathrm{mol}^{-1}$ (Co) $\mathrm{h}^{-1}$ at 2500 . In addition, the molecular weights gradually dropped from 45.0 to $33.6 \mathrm{~kg} \mathrm{~mol}^{-1}$ which is likely due to increased chain transfer to aluminum on increasing the amount of alkyl aluminum reagent (Figure 4).,40-42 On the other hand, the molecular weight distribution remained remarkably narrow $\left(M_{\mathrm{w}} / M_{\mathrm{n}}=1.41-1.74\right)$ across the range of $\mathrm{Al} /$ Co molar ratios.

Table 3 Ethylene polymerization results using Co1 with MAO as co-catalyst ${ }^{\mathrm{a}}$

\begin{tabular}{ccccccccc}
\hline Entry & $\mathrm{A} 1 / \mathrm{Co}$ & $\mathrm{T}\left({ }^{\circ} \mathrm{C}\right)$ & $\mathrm{t}(\mathrm{min})$ & Yield $(\mathrm{g})$ & Activity $^{\mathrm{b}}$ & $M_{\mathrm{w}}{ }^{\mathrm{c}}$ & $M_{\mathrm{w}} / M_{\mathrm{n}} \mathrm{c}^{\mathrm{c}}$ & $T_{\mathrm{m}}\left({ }^{\mathrm{o}}{ }^{\mathrm{C}}\right)^{\mathrm{d}}$ \\
\hline 1 & 500 & 30 & 30 & 0.93 & 0.37 & 45.0 & 1.72 & 133.8 \\
2 & 750 & 30 & 30 & 2.15 & 0.86 & 42.0 & 1.64 & 134.4 \\
3 & 1000 & 30 & 30 & 3.28 & 1.31 & 37.9 & 1.74 & 134.6 \\
4 & 1250 & 30 & 30 & 3.10 & 1.24 & 35.5 & 1.54 & 133.7 \\
5 & 1500 & 30 & 30 & 3.06 & 1.22 & 34.3 & 1.41 & 135.1 \\
6 & 2000 & 30 & 30 & 2.87 & 1.14 & 33.9 & 1.41 & 133.7 \\
7 & 2500 & 30 & 30 & 2.32 & 0.92 & 33.6 & 1.46 & 133.4 \\
8 & 1000 & 20 & 30 & 2.51 & 1.00 & 43.8 & 1.67 & 136.0 \\
9 & 1000 & 40 & 30 & 2.20 & 0.88 & 28.6 & 2.09 & 133.8 \\
10 & 1000 & 50 & 30 & 2.00 & 0.80 & 18.3 & 1.49 & 128.1 \\
11 & 1000 & 60 & 30 & 1.45 & 0.58 & 7.0 & 2.30 & 125.4 \\
12 & 1000 & 70 & 30 & 0.28 & 0.11 & 2.0 & 1.54 & 125.9 \\
13 & 1000 & 80 & 30 & trace & - & - & - & - \\
14 & 1000 & 30 & 30 & 1.47 & 0.58 & 25.6 & 2.36 & 132.2 \\
$15^{f}$ & 1000 & 30 & 30 & 0.25 & 0.10 & 3.7 & 2.50 & 125.5 \\
16 & 1000 & 30 & 5 & 0.65 & 1.56 & 25.3 & 1.53 & 132.2 \\
17 & 1000 & 30 & 15 & 1.71 & 1.37 & 25.4 & 1.54 & 133.8 \\
18 & 1000 & 30 & 45 & 4.66 & 1.24 & 58.8 & 2.78 & 135.2 \\
19 & 1000 & 30 & 60 & 4.75 & 0.95 & 77.1 & 3.48 & 134.2 \\
\hline
\end{tabular}



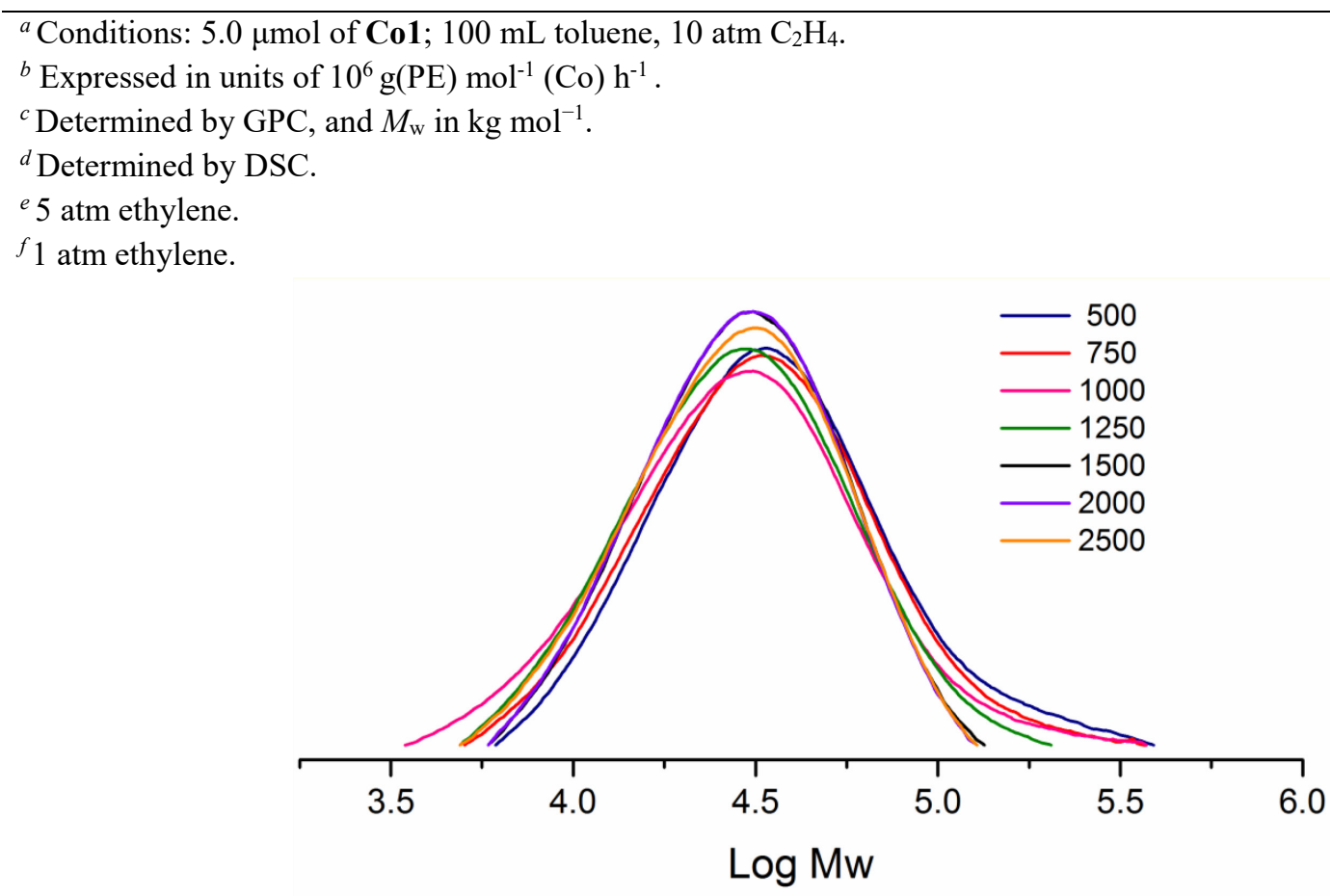

Figure 4 GPC curves for the polyethylenes obtained using Co1/MAO with various $\mathrm{Al} / \mathrm{Co}$ ratios (entries 1 7, Table 3)

By varying the temperature from 20 to $80{ }^{\circ} \mathrm{C}$ (entries $8,3,9-13$, Table 3 ) with the $\mathrm{Al} / \mathrm{Co}$ molar ratio kept at 1000 , the maximum activity of $1.31 \times 10^{6} \mathrm{~g}(\mathrm{PE}) \mathrm{mol}^{-1}(\mathrm{Co}) \mathrm{h}^{-1}$ could be again identified at $30{ }^{\circ} \mathrm{C}$. However, above $30{ }^{\circ} \mathrm{C}$ the activity of Co1/MAO steadily dropped reaching a minimum value at $80{ }^{\circ} \mathrm{C}$ at which point only a trace amount of polymer could be isolated (entry 13, Table 3). Moreover, the molecular weights of the polyethylenes lowered from 43.8 to $2.0 \mathrm{~kg}$ $\mathrm{mol}^{-1}$ as the temperature was raised, an observation that can be attributed to the higher rate of chain termination at higher temperature (Figure 5). ${ }^{4,42}$ On the other hand, the molecular weight distribution remained narrow $\left(M_{\mathrm{w}} / M_{\mathrm{n}}: 1.49-2.80\right)$ over the temperature range consistent with an active species displaying single-site behavior. 


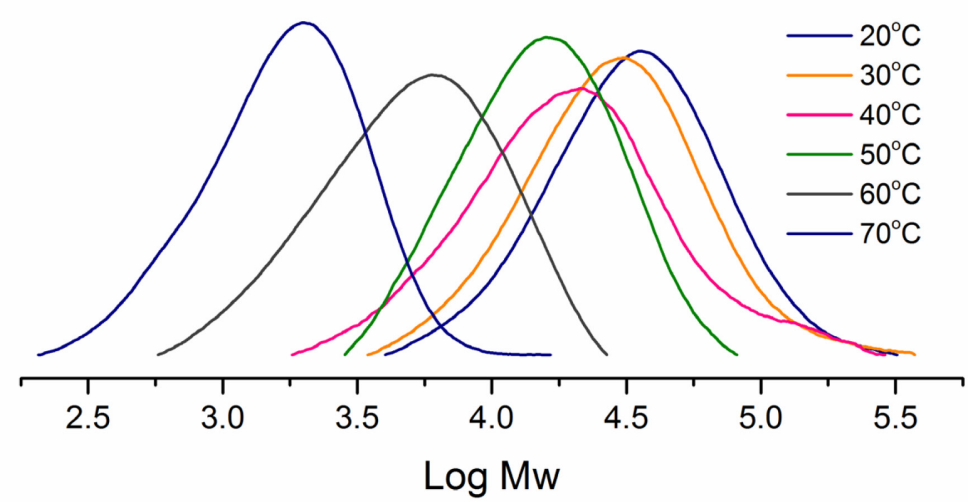

Figure 5 GPC curves for the polyethylenes obtained using Co1/MAO at different reaction temperatures (entries $8,3,9-13$, Table 3)

With the aim to gain some information as to the lifetime of the active species and the influence of the reaction time on the polymer properties, the polymerizations $(\mathrm{Al} / \mathrm{Co}=1000, \mathrm{~T}=$ $30{ }^{\circ} \mathrm{C}$ ) were conducted over various run times between 5 and 60 minutes (entries 3, 16 - 19, Table 3). The topmost activity of $1.56 \times 10^{6} \mathrm{~g}(\mathrm{PE}) \mathrm{mol}^{-1}(\mathrm{Co}) \mathrm{h}^{-1}$ was observed after 5 minutes (entry 16, Table 3), while prolonging the reaction time from 15 to 60 minutes led to a gradual drop in activity from 1.37 to $0.95 \times 10^{6} \mathrm{~g}(\mathrm{PE}) \mathrm{mol}^{-1}(\mathrm{Co}) \mathrm{h}^{-1}$. This would suggest the active species was rapidly formed on addition of MAO then gradually deactivated over time. Conversely, the molecular weight of the polymer increased from 25.3 to $77.1 \mathrm{~kg} \mathrm{~mol}^{-1}$ over the course of the reaction, highlighting that despite apparent deactivation there were sufficient active species present to maintain chain propagation (Figure 6). ${ }^{41,57}$ In terms of the molecular weight distribution, this showed some modest increase over time $\left(M_{\mathrm{w}} / M_{\mathrm{n}}: 1.53\right.$ to 3.48$)$, but nevertheless remained reasonably narrow even after one hour.

The effect of ethylene pressure on polymerization performance of Co1/MAO was also investigated. On lowering the pressure from 10 to $5 \mathrm{~atm}$, the activity decreased by more than half from $1.31 \times 10^{6} \mathrm{~g}(\mathrm{PE}) \mathrm{mol}^{-1}(\mathrm{Co}) \mathrm{h}^{-1}$ to $0.58 \times 10^{6} \mathrm{~g}(\mathrm{PE}) \mathrm{mol}^{-1}(\mathrm{Co}) \mathrm{h}^{-1}$ (entries 2, 14, Table 3). Further reduction in the pressure to 1 atm saw the activity drop to $0.10 \times 10^{6} \mathrm{~g}(\mathrm{PE}) \mathrm{mol}^{-1}(\mathrm{Co}) \mathrm{h}^{-1}$ (entry 15, Table 3). Likewise, the molecular weight of the polymer decreased with reduced 
ethylene pressure from 37.9 to $3.7 \mathrm{~kg} \mathrm{~mol}^{-1}$, while a narrow molecular weight distribution $\left(M_{\mathrm{w}} / M_{\mathrm{n}}\right.$ : $1.74-2.50)$ was a feature at all three pressures.

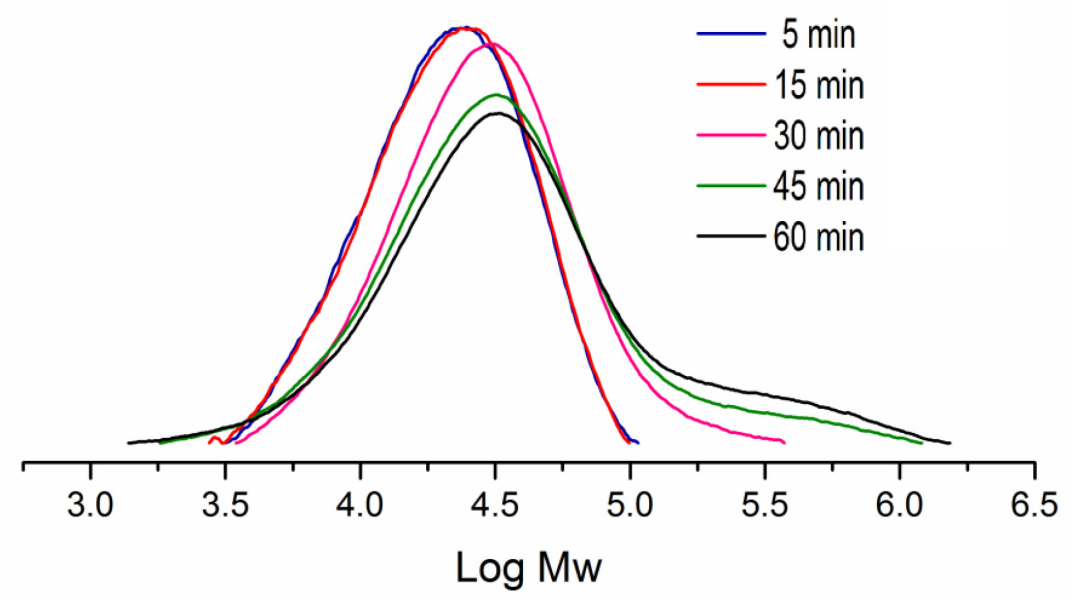

Figure 6 GPC curves for the polyethylenes obtained using Co1/MAO at different run times (entries 16 19, Table 3)

\section{Optimization of Co1/MMAO for ethylene polymerization}

As with Co1/MAO, a similar optimization process was performed this time using Co1 in combination with MMAO at 10 atm $\mathrm{C}_{2} \mathrm{H}_{4}$; the results are compiled in Table 4 . With the temperature at $30{ }^{\circ} \mathrm{C}$ and the run time at 30 minutes, the $\mathrm{Al} / \mathrm{Co}$ molar ratio was varied from 500 to 2500 (entries $1-7$, Table 4) leading to the highest activity of $1.63 \times 10^{6} \mathrm{~g}(\mathrm{PE}) \mathrm{mol}^{-1}(\mathrm{Co}) \mathrm{h}^{-1}$ reached with a ratio of 1000 (entry 3 , Table 4$)$; this compares to $1.31 \times 10^{6} \mathrm{~g}(\mathrm{PE}) \mathrm{mol}^{-1}(\mathrm{Co}) \mathrm{h}^{-1}$ for Co1/MAO under comparable conditions. Raising this ratio above 1000 resulted in a slow decrease in performance from $1.59 \times 10^{6} \mathrm{~g}(\mathrm{PE}) \mathrm{mol}^{-1}(\mathrm{Co}) \mathrm{h}^{-1}(\mathrm{Al} / \mathrm{Co}=1250)$ to $1.33 \times 10^{6} \mathrm{~g}$ (PE) $\mathrm{mol}^{-1}(\mathrm{Co}) \mathrm{h}^{-1}(\mathrm{Al} / \mathrm{Co}=2500)$. In addition, the molecular weight of the polymers gradually decreased from 64.8 to $42.7 \mathrm{~kg} \mathrm{~mol}^{-1}$ over the molar ratio range (Figure 7), which is notably higher than that seen with $\mathbf{C o 1} / \mathrm{MAO}$ (45.0 to $33.6 \mathrm{~kg} \mathrm{~mol}^{-1}$ ). It uncertain as to this difference between activators but may derive from higher amounts of $\mathrm{AlMe}_{3}$ that are present in commercial samples of MMAO as compared to that in MAO. By contrast, the molecular weight distribution was particularly narrow with little variation across the range $\left(M_{\mathrm{w}} / M_{\mathrm{n}}: 1.63-1.33\right)$. 
Table 4 Ethylene polymerization results of $\mathrm{Co1}$ with MMAO as co-catalyst $\mathrm{t}^{\mathrm{a}}$

\begin{tabular}{ccccccccc}
\hline Entry & $\mathrm{Al} / \mathrm{Co}$ & $\mathrm{T}\left({ }^{\circ} \mathrm{C}\right)$ & $\mathrm{t}(\mathrm{min})$ & Yield $(\mathrm{g})$ & Activity $^{\mathrm{b}}$ & $M_{\mathrm{w}}{ }^{\mathrm{c}}$ & $M_{\mathrm{w}} / M_{\mathrm{n}}{ }^{\mathrm{c}}$ & $T_{\mathrm{m}}\left({ }^{\circ} \mathrm{C}\right)^{\mathrm{d}}$ \\
\hline 1 & 500 & 30 & 30 & 3.64 & 1.46 & 64.8 & 3.02 & 135.2 \\
2 & 750 & 30 & 30 & 3.77 & 1.51 & 64.1 & 3.60 & 134.8 \\
3 & 1000 & 30 & 30 & 4.06 & 1.63 & 50.3 & 1.84 & 133.8 \\
4 & 1250 & 30 & 30 & 3.97 & 1.59 & 46.5 & 1.78 & 134.0 \\
5 & 1500 & 30 & 30 & 3.54 & 1.42 & 46.3 & 1.94 & 134.4 \\
6 & 2000 & 30 & 30 & 3.45 & 1.38 & 45.0 & 1.75 & 134.0 \\
7 & 2500 & 30 & 30 & 3.32 & 1.33 & 42.7 & 1.35 & 134.2 \\
8 & 1000 & 20 & 30 & 3.98 & 1.60 & 129.2 & 2.50 & 135.1 \\
9 & 1000 & 40 & 30 & 4.68 & 1.87 & 12.8 & 2.68 & 130.7 \\
10 & 1000 & 50 & 30 & 3.85 & 1.54 & 6.6 & 2.32 & 127.9 \\
11 & 1000 & 60 & 30 & 2.75 & 1.10 & 2.9 & 1.90 & 124.2 \\
12 & 1000 & 70 & 30 & 1.50 & 0.60 & 1.7 & 1.64 & 122.5 \\
13 & 1000 & 80 & 30 & 0.36 & 0.14 & 1.7 & 1.49 & 119.4 \\
14 & 1000 & 40 & 5 & 0.89 & 0.36 & 7.9 & 1.57 & 128.9 \\
15 & 1000 & 40 & 15 & 2.15 & 2.87 & 12.6 & 2.03 & 131.0 \\
16 & 1000 & 40 & 45 & 5.16 & 1.37 & 22.3 & 1.64 & 131.9 \\
17 & 1000 & 40 & 60 & 6.44 & 1.29 & 23.5 & 1.69 & 133.1 \\
$18^{e}$ & 1000 & 40 & 30 & 1.92 & 0.76 & 5.6 & 1.58 & 129.1 \\
\hline
\end{tabular}

${ }^{a}$ Conditions: $5.0 \mu \mathrm{mol}$ of Co1; $100 \mathrm{~mL}$ toluene, 10 atm $\mathrm{C}_{2} \mathrm{H}_{4}$.

${ }^{b}$ Expressed in units of $10^{6} \mathrm{~g}(\mathrm{PE}) \mathrm{mol}^{-1}(\mathrm{Co}) \mathrm{h}^{-1}$.

${ }^{c}$ Determined by GPC, and $M_{\mathrm{w}}$ in $\mathrm{kg} \mathrm{mol}^{-1}$.

${ }^{d}$ Determined by DSC.

e 5 atm ethylene.

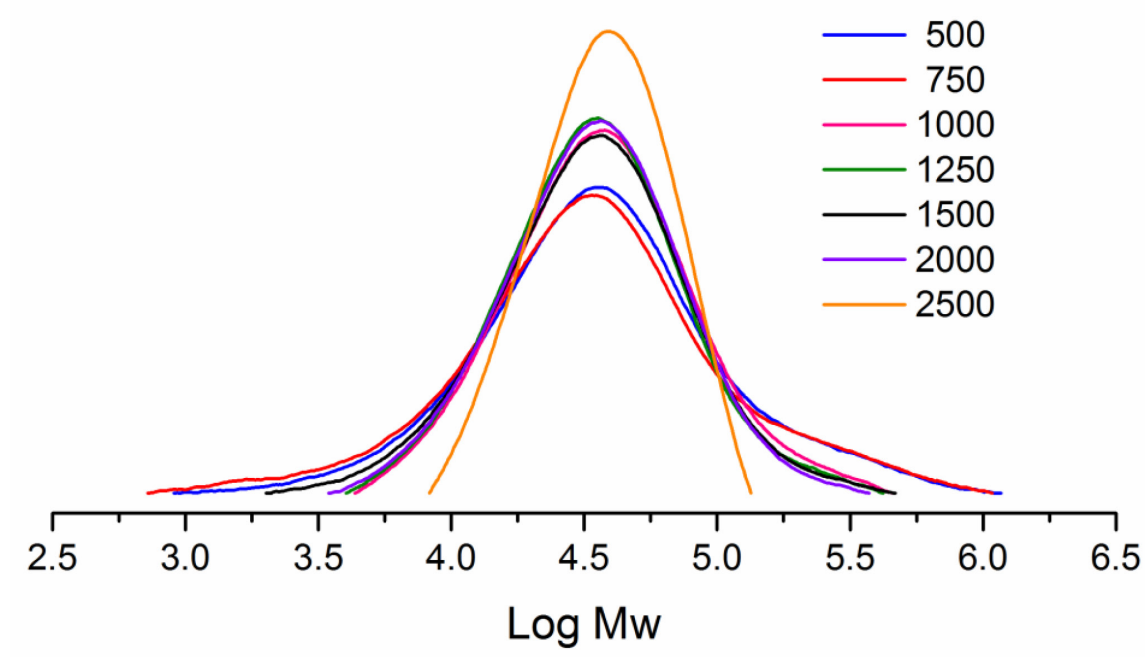

Figure 7 GPC curves for the polyethylenes obtained using Co1/MMAO with various $\mathrm{Al} / \mathrm{Co}$ ratios (entries $1-7$, Table 4) 
With the $\mathrm{Al} / \mathrm{Co}$ molar ratio maintained at 1000 , the run temperature was varied between 20 and $80{ }^{\circ} \mathrm{C}$ (entries 3, 8 - 13, Table 4). The optimum reaction temperature was observed at $40{ }^{\circ} \mathrm{C}$ with an activity of $1.87 \times 10^{6} \mathrm{~g}(\mathrm{PE}) \mathrm{mol}^{-1}(\mathrm{Co}) \mathrm{h}^{-1}$ (entry 9 , Table 4$)$. Above $40{ }^{\circ} \mathrm{C}$ the catalytic activity steadily decreased reaching a minimum value of $0.14 \times 10^{6} \mathrm{~g}(\mathrm{PE}) \mathrm{mol}^{-1}(\mathrm{Co}) \mathrm{h}^{-1}$ at $80^{\circ} \mathrm{C}$; nonetheless this value is significantly higher than that observed with Co1/MAO at the same temperature (see entry 13, Table 4). The molecular weight of the polyethylene was found to rapidly drop from $129.2 \mathrm{~kg} \mathrm{~mol}^{-1}$ at $20{ }^{\circ} \mathrm{C}$ to $12.8 \mathrm{~kg} \mathrm{~mol}^{-1}$ at $40{ }^{\circ} \mathrm{C}$ and then assume a more gradual decline reaching a minimum value of $1.7 \mathrm{~kg} \mathrm{~mol}^{-1}$ at $80{ }^{\circ} \mathrm{C}$ (Figure 8). Across the entire temperature range, the molecular weight distribution remained narrow $\left(M_{\mathrm{w}} / M_{\mathrm{n}}: 1.49-2.68\right)$. In comparison with the variable temperature runs performed with Co1/MAO, the molecular weight of the polymers produced using Co1/MMAO was generally higher.

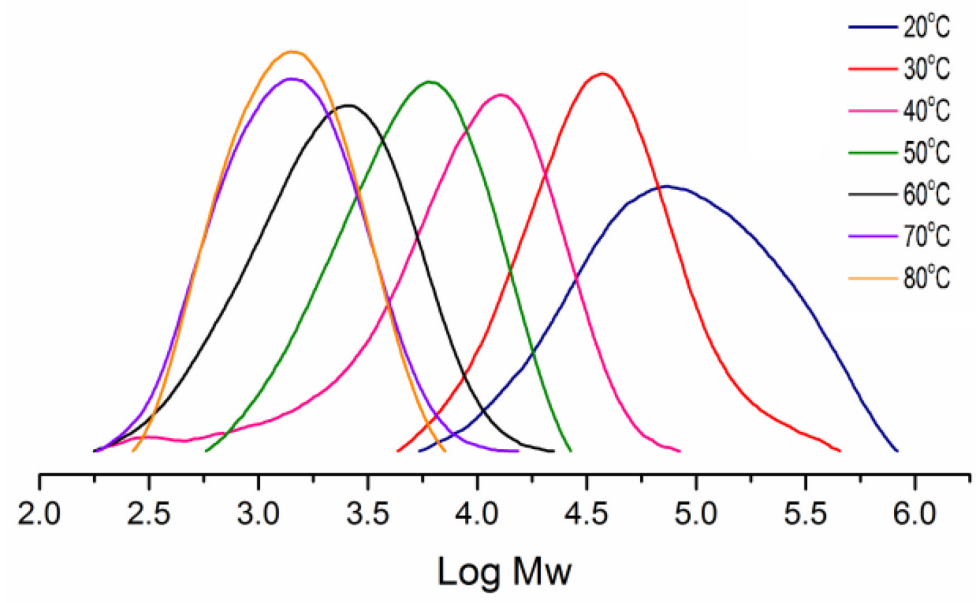

Figure 8 GPC curves for the polyethylenes obtained using Co1/MMAO at different reaction temperatures (entries $3,8-13$, Table 4)

The effect of time on the catalytic activity and polymer properties was then investigated using Co1/MMAO at $40{ }^{\circ} \mathrm{C}$ with the $\mathrm{Al} / \mathrm{Co}$ molar ratio at 1000 . The polymerizations were conducted over $5,15,30,45$ and 60 minute run times resulting in the highest activity of $2.87 \times 10^{6}$ $\mathrm{g}(\mathrm{PE}) \mathrm{mol}^{-1}(\mathrm{Co}) \mathrm{h}^{-1}$ being achieved after 15 minutes (entries 14 - 15, 9, 16 - 17, Table 4). Notably, this value compares to just 5 minutes with MAO which highlights the slower catalyst induction period needed with MMAO. However, extending the run time beyond 15 minutes 
results in slow catalyst deactivation with the activity reaching a minimum value of $1.29 \times 10^{6} \mathrm{~g}$ (PE) $\mathrm{mol}^{-1}(\mathrm{Co}) \mathrm{h}^{-1}$ after one hour. ${ }^{39,57}$ Nevertheless, the molecular weight of the polymer continued to rise with time reaching a maximum of $23.5 \mathrm{~kg} \mathrm{~mol}^{-1}$ after one hour (Figure 9), while a narrow molecular weight distribution was observed with all these runs $\left(M_{\mathrm{w}} / M_{\mathrm{n}}: 1.57-2.68\right)$.

Reducing the ethylene pressure from 10 to 5 atm saw the activity drop from $1.87 \times 10^{6} \mathrm{~g}$ (PE) $\mathrm{mol}^{-1}(\mathrm{Co}) \mathrm{h}^{-1}$ to $0.76 \times 10^{6} \mathrm{~g}(\mathrm{PE}) \mathrm{mol}^{-1}(\mathrm{Co}) \mathrm{h}^{-1}$ (entries 9, 18 Table 4). On the other hand, the molecular weight of the polymer fell from $12.8 \mathrm{~kg} \mathrm{~mol}^{-1}$ at $10 \mathrm{~atm}$ to $5.6 \mathrm{~kg} \mathrm{~mol}^{-1}$ at $5 \mathrm{~atm}$, while little variation in the polydispersity was observed $\left(M_{\mathrm{w}} / M_{\mathrm{n}}: 1.58-2.68\right)$.

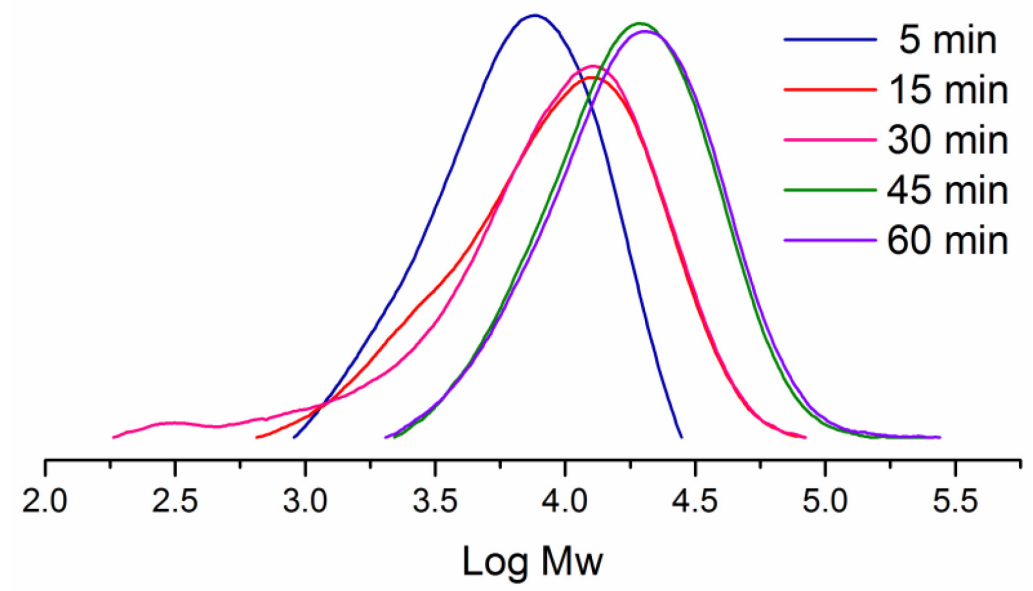

Figure 9 GPC curves for the polyethylenes obtained using Co1/MMAO at different reaction times (entries $14-17$, Table 4)

For the purposes of comparison, the activity and molecular weight data for the polymer generated using Co1 are shown in Figure 10 alongside that obtained for structurally related fused examples of $\mathbf{C}, \mathbf{E}$ and $\mathbf{F}$ (all polymerizations were performed at 10 atm $\mathrm{C}_{2} \mathrm{H}_{4}$ over 30 minutes using MMAO as co-catalyst). Two key points emerge from inspection of the figure. Firstly, the presence of a ortho-benzhydryl group in Co1 has the effect of increasing the molecular weight of the polymer when compared to $\mathbf{C}$ but not as significantly as that seen for the ortho-cyclohexyl derivative E. On the other hand, the catalytic activity for Co1 is slightly lower than that observed with $\mathbf{C}$ and $\mathbf{E}$ but significantly higher when compared to the oligomerization $N, N, O$-precatalyst $\mathbf{F}$. 


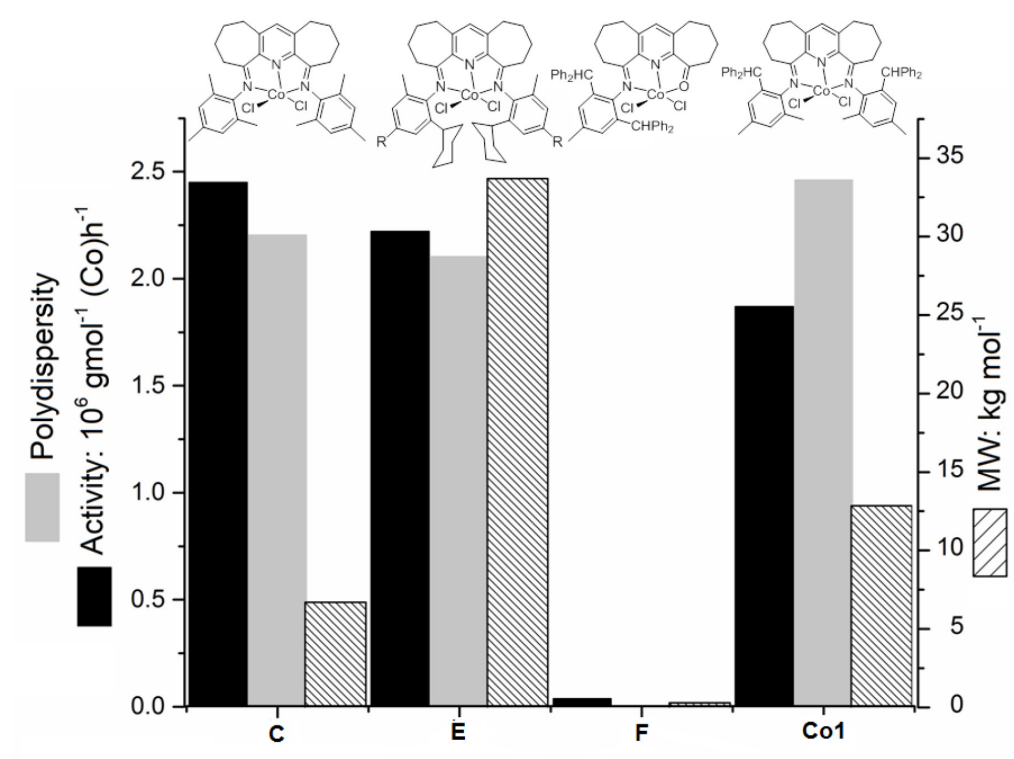

Figure 10 Comparative catalytic performance of $\mathbf{C o 1}$ (entry 9, Table 3) with cobalt-containing $\mathbf{C},{ }^{41} \mathbf{E}^{46}$ and $\mathbf{F}^{48}$ (Chart 1); all polymerizations were recorded at 10 atm $\mathrm{C}_{2} \mathrm{H}_{4}, 30 \mathrm{~min}$ using MMAO as co-catalyst. Other comparative data can be found in the SI.

\section{General catalytic screen of Co1 - Co8 with MAO and MMAO}

With the optimal conditions established for $\mathrm{Co1} / \mathrm{MAO}\left[\mathrm{Al} / \mathrm{Co}\right.$ ratio $=1000$, temperature $=30{ }^{\circ} \mathrm{C}$ and run time $=30$ minutes, $\left.10 \mathrm{~atm} \mathrm{C}_{2} \mathrm{H}_{4}\right]$ and $\mathbf{C o 1} / \mathrm{MMAO}[\mathrm{Al} / \mathrm{Co}$ ratio $=1000$, run temperature $40{ }^{\circ} \mathrm{C}$ and run time $=30$ minutes], the remaining seven precatalysts were investigated using the corresponding set of parameters for each co-catalyst; the results of these polymerization tests along with those for $\mathbf{C o 1}$ are collected in Table 5.

Several points can be identified by examination of the data. Firstly, with MAO as cocatalyst, Co1 - Co5 all displayed good activities with their values falling in the range $1.31-0.15 \times$ $10^{6} \mathrm{~g}(\mathrm{PE}) \mathrm{mol}^{-1}(\mathrm{Co}) \mathrm{h}^{-1}$ (entries 1 - 5, Table 5). Similarly with MMAO, Co1 - Co5 showed good activity and indeed slightly higher than that observed with MAO $\left(1.87-0.10 \times 10^{6} \mathrm{~g}(\mathrm{PE}) \mathrm{mol}^{-1}\right.$ (Co) $\mathrm{h}^{-1}$; entries 9 - 26, Table 5). By contrast, Co6 - Co8 gave only trace amounts of polymer irrespective of the co-catalyst employed (entries $6-9,14-15$, Table 5). In terms of the relative performance of the precatalysts, the same order was observed for both activators namely: Co1 > $\mathrm{Co5}>\mathrm{Co2}>\mathrm{Co3}>\mathrm{Co4}>\mathrm{Co6} \sim \mathrm{Co} 7 \sim \mathrm{Co8}$ (Figure 11). Clearly, steric and electronic properties of the $\mathrm{N}$-aryl groups are influential on catalytic activity. ${ }^{58}$ With regard to steric effects, 
the best activities were achieved by pairing the least bulky ortho- $\mathrm{R}^{1}$ substituents e.g., methyl (Co1) alongside an ortho-benzhydryl group. ${ }^{2-3,34}$ On the other hand, by the pairing of two orthobenzhydryl groups $(\mathbf{C o 6}-\mathbf{C o 8})$ leads to too much steric protection and hence prevents efficient approach of the ethylene monomer to the metal center and in-turn negligible activities. ${ }^{13,37}$ The effects of electronic changes are more subtle and may explain the higher activity of Co1 over Co2 in which the para-substituent is either a methyl or a benzhydryl, respectively. Similarly, the superior activity of ortho-chloro Co5 when compared to ortho-alkyls Co2 - Co4 may have an electronic origin as well as steric.

Secondly, the molecular weight of the polymers obtained using Co1 - Co5/MAO range from 28.7 - $53.3 \mathrm{~kg} \mathrm{~mol}^{-1}$ which is comparable to 12.3 - $59.4 \mathrm{~kg} \mathrm{~mol}^{-1}$ obtained with Co1 Co5/MMAO (entries $1-5,9-13$, Table 5). In comparison with previously reported $\mathbf{C}$ (Chart 1) which incorporate less sterically bulky aryl groups $\left(\mathrm{Ar}=2,6-\mathrm{Me}_{2} \mathrm{Ph}, 2,6-\mathrm{Et}_{2} \mathrm{Ph}, 2,6-i-\mathrm{Pr}_{2} \mathrm{Ph}, 2,4,6-\right.$ $\left.\mathrm{Me}_{2} \mathrm{Ph}, 2,6-\mathrm{Et}_{2}-4-\mathrm{MePh}\right){ }^{41}$ the molecular weights in this study are generally an order of magnitude higher. This observation can be accredited to the ortho-bulky substituent more effectively preventing chain termination in manner similar to that previously reported. ${ }^{13,46}$ Indeed, the more bulky benzhydryl/i-Pr and benzhydryl/Cl ortho-pairings in $\mathbf{C o 4}$ and $\mathrm{Co5}$ afford the highest molecular weight of the Co1 - Co5 series. As a general observation, the molecular weight distributions are in all runs narrow regardless of precatalyst and co-catalyst.

Table 5 Ethylene polymerization results using $\mathbf{C o 1}-\mathbf{C o 8}$ with either MAO or MMAO as co-catalyst ${ }^{\mathrm{a}}$

\begin{tabular}{|c|c|c|c|c|c|c|c|c|c|c|}
\hline Entry & Precat. & Co-cat. & $\mathrm{Al} / \mathrm{Co}$ & $\mathrm{T}\left({ }^{\circ} \mathrm{C}\right)$ & $\mathrm{t}(\mathrm{min})$ & Yield (g) & Activity $^{\mathrm{b}}$ & $M_{\mathrm{w}}{ }^{\mathrm{c}}$ & $M_{\mathrm{w}} / M_{\mathrm{n}}^{\mathrm{c}}$ & $T_{\mathrm{m}}\left({ }^{\circ} \mathrm{C}\right)^{\mathrm{d}}$ \\
\hline 1 & Co1 & MAO & 1000 & 30 & 30 & 3.28 & 1.31 & 37.9 & 1.74 & 134.6 \\
\hline 2 & $\mathrm{Co2}$ & MAO & 1000 & 30 & 30 & 1.99 & 0.79 & 33.8 & 1.78 & 132.3 \\
\hline 3 & $\mathrm{Co3}$ & MAO & 1000 & 30 & 30 & 1.30 & 0.52 & 28.7 & 2.06 & 131.2 \\
\hline 4 & Co4 & MAO & 1000 & 30 & 30 & 0.37 & 0.15 & 53.3 & 1.38 & 128.0 \\
\hline 5 & Co5 & MAO & 1000 & 30 & 30 & 3.12 & 1.25 & 44.3 & 1.62 & 133.7 \\
\hline 6 & Co6 & MAO & 1000 & 30 & 30 & trace & - & - & - & - \\
\hline 7 & $\mathrm{Co} 7$ & MAO & 1000 & 30 & 30 & trace & - & - & - & - \\
\hline 8 & $\mathrm{Co8}$ & MAO & 1000 & 30 & 30 & trace & - & - & - & - \\
\hline 9 & Co1 & MMAO & 1000 & 40 & 30 & 4.68 & 1.87 & 12.8 & 2.68 & 130.7 \\
\hline 10 & $\mathrm{Co} 2$ & MMAO & 1000 & 40 & 30 & 1.60 & 0.64 & 12.3 & 1.73 & 130.3 \\
\hline 11 & $\mathrm{Co3}$ & MMAO & 1000 & 40 & 30 & 1.10 & 0.44 & 17.6 & 1.52 & 131.7 \\
\hline 12 & Co4 & MMAO & 1000 & 40 & 30 & 0.24 & 0.10 & 51.3 & 1.35 & 130.0 \\
\hline 13 & $\mathrm{Co5}$ & MMAO & 1000 & 40 & 30 & 3.89 & 1.56 & 59.4 & 1.59 & 134.1 \\
\hline 14 & Co6 & MMAO & 1000 & 40 & 30 & trace & - & - & - & - \\
\hline
\end{tabular}




\begin{tabular}{|c|c|c|c|c|c|c|c|c|c|c|}
\hline 15 & $\mathrm{Co} 7$ & MMAO & 1000 & 40 & 30 & trace & - & - & - & - \\
\hline 16 & Co8 & MMAO & 1000 & 40 & 30 & trace & - & - & - & - \\
\hline
\end{tabular}

${ }^{a}$ Conditions: $5.0 \mu \mathrm{mol}$ of precatalyst; $100 \mathrm{~mL}$ toluene, 10 atm ethylene.

${ }^{b}$ Values in units of $10^{6} \mathrm{~g}(\mathrm{PE}) \mathrm{mol}^{-1}(\mathrm{Co}) \mathrm{h}^{-1}$.

${ }^{c}$ Determined by GPC, and $M_{\mathrm{w}}$ in $\mathrm{kg} \mathrm{mol}^{-1}$.

${ }^{d}$ Determined by DSC.

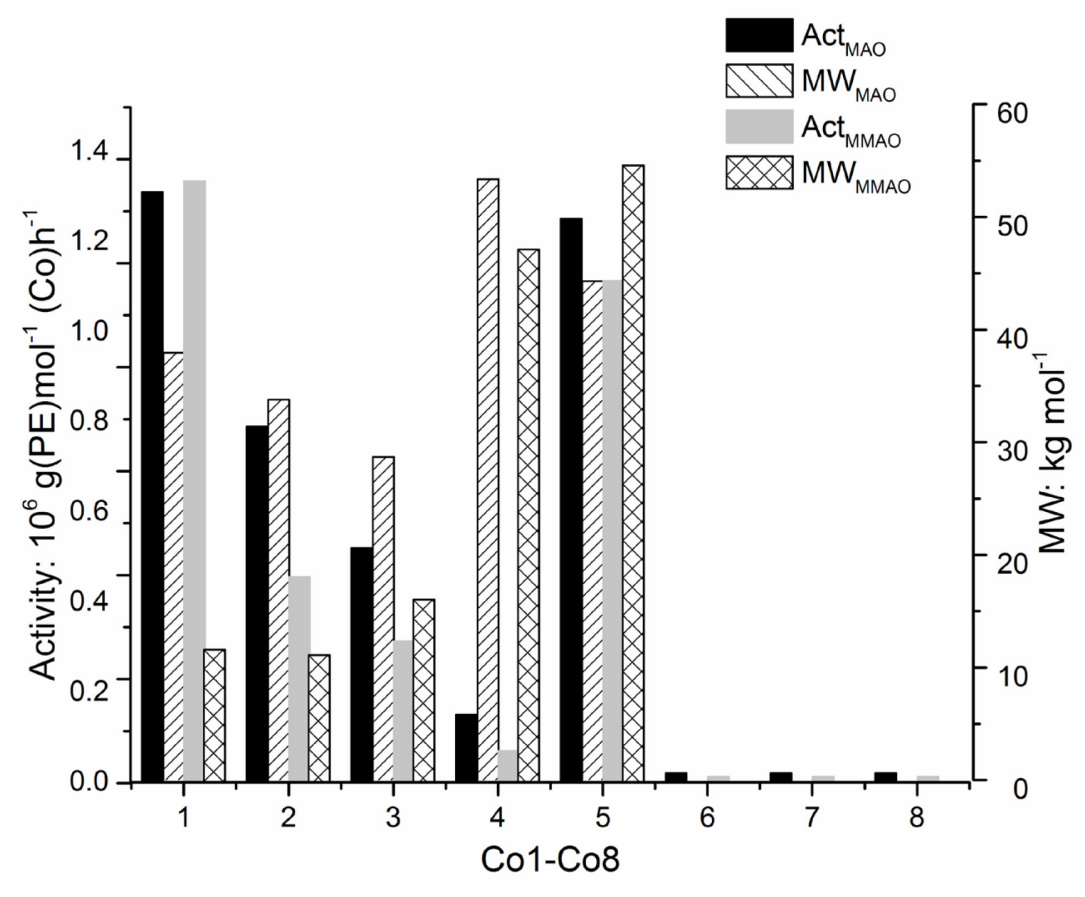

Figure 11 Relative catalytic activity observed for Co1 - Co8 with the two different activators

Thirdly, the polymers generated using Co1 - Co5/MAO and Co1 - Co5/MMAO show similar melt temperatures falling in the range $128.0-134.6{ }^{\circ} \mathrm{C}$ (entries $1-5,9-13$, Table 5), values which are characteristic of highly linear polyethylenes. To further investigate the polymer structure, representative samples prepared using Co1/MAO and Co1/MMAO were the subject of high-temperature ${ }^{1} \mathrm{H} /{ }^{13} \mathrm{C}$ NMR studies (recorded at $135{ }^{\circ} \mathrm{C}$ in deuterated 1,1,2,2-tetrachloroethane$\left.d_{2}\right)$.

The ${ }^{13} \mathrm{C}$ NMR spectrum for the sample synthesized using Co1/MAO (entry 1, Table 5) revealed an intense peak at $\delta 30.0$ for the $-\left(\mathrm{CH}_{2}\right)_{n}$ - repeat in a linear polymer along with weaker upfield peaks $\left(\delta 32.20\left(\mathrm{C}_{3}\right), 22.91\left(\mathrm{C}_{2}\right), 14.35\left(\mathrm{C}_{1}\right)\right)$ that can be assigned to a saturated $n$-propyl end-group (Figure 12). Closer examination of the downfield region shows two very weak peaks between $\delta 140-110$ that can be attributed to a vinyl end-group. The presence of this unsaturation 
would suggest there is some vinyl-terminated polyethylene in the sample but based on the relative intensities of the methyl and $\mathrm{CH}_{2}=\mathrm{CH}$ resonances, a fully saturated polymer is likely an additional component. This finding is corroborated in the ${ }^{1} \mathrm{H}$ NMR spectrum which reveals downfield vinylic protons for $\mathrm{a}$ and $\mathrm{b}$ integrating to 2 and 1, respectively, along with an upfield methyl end group at $\delta 0.97$ integrating to $c a .9 \mathrm{H}$ (see insert in Figure 12), the latter high intensity signal is supportive of the co-existence of a fully saturated polymer. ${ }^{39,40}$ Overall these findings point towards both $\beta-\mathrm{H}$ elimination and transfer to aluminum being operative and competitive with MAO as co-catalyst. ${ }^{40,}$ 59

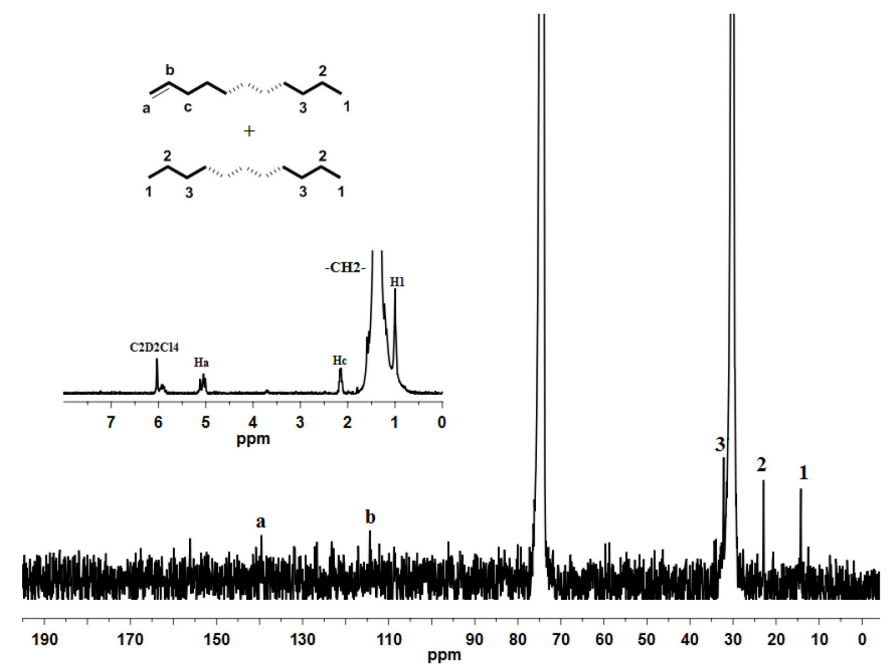

Figure $12{ }^{13} \mathrm{C}$ NMR spectrum of the polyethylene obtained using Co1/MAO (entry 1, Table 3) including an insert of the ${ }^{1} \mathrm{H}$ NMR spectrum; recorded in 1,1,2,2-tetrachloroethane- $d_{2}$ at $135{ }^{\circ} \mathrm{C}$

For the polymer sample obtained using Co1/MMAO (entry 9, Table 5), the ${ }^{13} \mathrm{C}$ NMR spectrum again reveals a high intensity peak around $\delta 30.00$, in accord with a linear polyethylene (Figure 13). Likewise, upfield signals corresponding to an $n$-propyl end-group $\left(\mathrm{C}_{1}, \mathrm{C}_{2}\right.$ and $\left.\mathrm{C}_{3}\right)$ can be clearly seen while less intense vinylic carbons can be observed in the downfield region. ${ }^{35,42,45}$ Once again it would appear that both chain transfer to aluminum and $\beta-\mathrm{H}$ elimination are operating as competitive termination pathways. Furthermore, no evidence for iso-butyl end-groups could be detected highlighting the preference for the polymerization to undergo termination by chain transfer to $\mathrm{AlMe}_{3}$ rather than $\mathrm{Al}\left(i-\mathrm{Bu}_{3}\right)$ and its derivatives present in MMAO. 


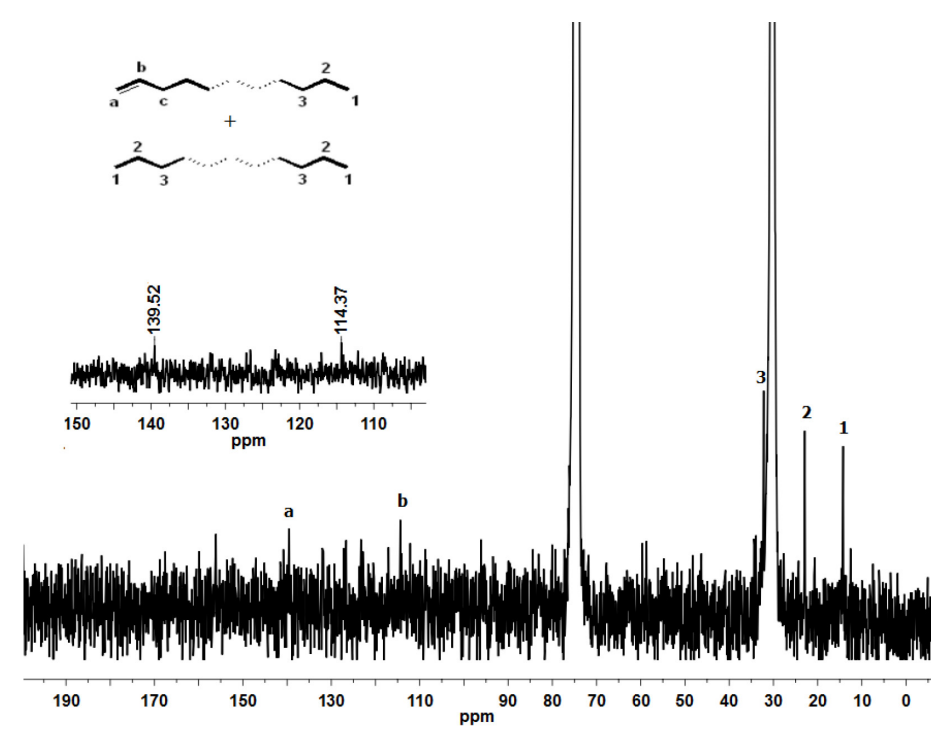

Figure $13{ }^{13} \mathrm{C}$ NMR spectrum of the polyethylene obtained using Co1/MMAO (entry 9, Table 4); recorded in 1,1,2,2-tetrachloroethane- $d_{2}$ at $135^{\circ} \mathrm{C}$

\section{Conclusions}

A one-pot template approach has been successfully employed to generate the sterically and electronically distinct cobalt(II) chloride chelates, Co1 - Co8, in reasonable yield. Full characterization of the complexes has been undertaken including in three cases by single crystal X-ray diffraction. On activation with MMAO or MAO, Co1 - Co5 exhibited high activity for ethylene polymerization and produced low molecular weight, highly linear polyethylenes exhibiting narrow molecular weight distributions. Importantly, the molecular weight is higher than in their less sterically bulky counterparts ( $\mathbf{C}$ and $\mathbf{F}$ Chart 1), highlighting the beneficial effect of benzhydryl substitution on chain propagation. On the other hand, the molecular weight obtained is not as high as that seen for ortho-cyclohexyl E. End-group analysis of the polymers formed using either Co1/MAO or Co1/MMAO provided evidence for both $\beta$-hydrogen elimination and chain transfer to aluminum being operative during chain termination. By stark contrast, $\mathbf{C o 6}$ - $\mathbf{C o 8}$ when activated with either aluminoxane co-catalyst gave only trace amounts of polymer. In terms of relative performance, the complexes containing the least bulky benzhydryl $/ \mathrm{R}^{1}$ ortho-pairings favored higher activities while the highest molecular weight polymer could be obtained be with a more bulky combination. 


\section{Acknowledgements}

This work was supported by the National Natural Science Foundation of China (Nos. 21374123 and U1362204). CB is grateful to the CAS-TWAS President's fellowship. GAS thanks the Chinese Academy of Sciences for a President's International Fellowship for Visiting Scientists.

\section{References}

1. B. L. Small, M. Brookhart, Highly active iron and cobalt catalysts for the polymerization of ethylene, J. Am. Chem. Soc. 120 (1998) 4049-4050.

2. G. J. P. Britovsek, V. C. Gibson, B. S. Kimberley, P. J. Maddox, S. J. McTavish, G. A. Solan, A. J. P. White, D. J. Williams, Novel olefin polymerization catalysts based on iron and cobalt, Chem. Commun. (1998) 849-850.

3. V.C. Gibson, C. Redshaw, G. A. Solan, Bis(imino)pyridines: Surprisingly reactive ligands and a gateway to new families of catalysts, Chem. Rev. 107 (2007) 1745-1776.

4. G. J. P. Britovsek, M. Bruce, V. C. Gibson, B. S. Kimberley, P. J. Maddox, S. Mastroianni, S. J. McTavish, C. Redshaw, G. A. Solan, S. Strömberg, A. J. P. White, D. J. Williams, Iron and cobalt ethylene polymerization catalysts bearing 2,6-bis(imino)pyridyl ligands: Synthesis, structures and polymerization studies, J. Am. Chem. Soc. 121 (1999) 87288740.

5. G. J. P. Britovsek, M. Bruce, V. C. Gibson, S. K. Spitzmesser, K. P. Tellman, A. J. P. White, D. J. Williams, Cationic 2,6-bis(imino)pyridine iron and cobalt complexes: Synthesis, structures, ethylene polymerisation and ethylene/polar monomer copolymerisation studies, J. Chem. Soc., Dalton Trans. (2002) 1159-1171.

6. J. Ma, C. Feng, S. Wang, K.-Q. Zhao, W.-H. Sun, C. Redshaw, G. A. Solan, Bi- and tridentate imino-based iron and cobalt pre-catalysts for ethylene oligo-/polymerization, Inorg. Chem. Front. 1 (2014) 14-34. 
7. B. L. Small, M. Brookhart, Polymerization of propylene by a new generation of iron catalysts: Mechanisms of chain initiation, propagation, and termination, Macromolecules. 32 (1999) 2120-2130.

8. T. M. Smit, A. K. Tomov, G. J. P. Britovsek, V. C. Gibson, A. J. P. White, D. J. Williams, The effect of imine-carbon substituents in bis(imino)pyridine-based ethylene polymerisation catalysts across the transition series, Catal. Sci. Technol. 2 (2012) 643-655.

9. S. McTavish, G. J. P. Britovsek, T. M. Smit, V. C. Gibson, A. J. P. White, D. J. Williams, Iron-based ethylene polymerization catalysts supported by bis(imino)pyridine ligands: Derivatization via deprotonation/alkylation at the ketimine methyl position, J. Mol. Catal. A: Chem. 261 (2007) 293-300.

10. G. J. P. Britovsek, V. C. Gibson, B. S. Kimberley, S. Mastroianni, C. Redshaw, G. A. Solan, A. J. P. White, D. J. Williams, Bis(imino)pyridyl iron and cobalt complexes: the effect of nitrogen substituents on ethylene oligomerisation and polymerisation, J. Chem. Soc, Dalton Trans. (2001) 1639-1644.

11. J. Yu, H. Liu, W. Zhang, X. Hao, W.-H. Sun, Access to highly active and thermally stable iron procatalysts using bulky 2-[1-(2,6-dibenzhydryl-4-methylphenylimino)ethyl]-6-[1(arylimino)ethyl]pyridine ligands, Chem Commun. 47 (2011) 3257-3259.

12. J. Yu, W. Huang, L. Wang, C. Redshaw, W.-H. Sun, 2-[1-(2,6-Dibenzhydryl-4methylphenylimino)ethyl]-6-[1-(arylimino)ethyl]-pyridylcobalt(II) dichlorides: Synthesis, characterization and ethylene polymerization behavior, Dalton Trans. 40 (2011) 1020910214.

13. S. Wang, B. Li, T. Liang, C. Redshaw, Y. Li, W.-H. Sun, Synthesis, characterization and catalytic behavior toward ethylene of 2-[1-(4,6-dimethyl-2-benzhydrylphenylimino)ethyl]6-[1-(arylimino)ethyl]-pyridylmetal (iron or cobalt) chlorides, Dalton Trans. 42 (2013) 9188-9197. 
14. W. Zhao, J. Yu, S. Song, W. Yang, H. Liu, X. Hao, C. Redshaw, W.-H. Sun, Controlling the ethylene polymerization parameters in iron pre-catalysts of the type 2-[1-(2,4dibenzhydryl-6-methylphenylimino)ethyl]-6-[1-(arylimino)ethyl]pyridyliron dichloride, Polymer. 53 (2012) 130-137.

15. X. Cao, F. He, W. Zhao, Z. Cai, X. Hao, T. Shiono, C. Redshaw, W.-H. Sun, 2-[1-(2,6dibenzhydryl-4-chlorophenylimino)ethyl]-6-[1-(arylimino)ethyl]pyridyliron(II) dichlorides: Synthesis, characterization and ethylene polymerization behavior, Polymer. 53 (2012) 1870-1880.

16. F. He, W. Zhao, X.-P. Cao, T. Liang, C. Redshaw, W.-H. Sun, 2-[1-(2,6-dibenzhydryl-4chlorophenylimino)ethyl]-6-[1-aryliminoethyl]pyridylcobalt dichlorides: Synthesis, characterization and ethylene polymerization behavior, J. Organomet. Chem. 713 (2012) $209-216$.

17. J. Lai, W. Zhao, W. Yang, C. Redshaw, T. Liang, Y. Liu, W.-H. Sun, 2-[1-(2,4dibenzhydryl-6-methylphenylimino)ethyl]-6-[1-(arylimino)ethyl]pyridylcobalt dichlorides: Synthesis, characterization and ethylene polymerization behavior, Polym. Chem. 3 (2012) 787-793.

18. W.-H. Sun, W. Zhao, J. Yu, W. Zhang, X. Hao, C. Redshaw, Enhancing the activity and thermal stability of iron precatalysts using 2-(1-\{2,6-bis[bis(4-fluorophenyl)methyl]-4methylphenylimino\} ethyl)-6-[1-(arylimino)ethyl]pyridines, Macromol. Chem. Phys. 213 (2012) 1266-1273.

19. W. Zhang, S. Wang, S. Du, C.-Y. Guo, X. Hao, W.-H. Sun, 2-(1-(2,4-Bis((di(4fluorophenyl)methyl)-6-methylphenylimino)ethyl)-6-(1-(arylimino)ethyl)pyridylmetal (iron or cobalt) Complexes: Synthesis, characterization, and ethylene polymerization behavior, Macromol. Chem. Phys. 215 (2014) 1797-1809.

20. E. Yue, Y. Zeng, W. Zhang, Y. Sun, X.-P. Cao, W.-H. Sun, Highly linear polyethylenes using the 2-(1-(2,4-dibenzhydrylnaphthylimino)ethyl)-6-(1-(arylimino)ethyl)-pyridylcobalt 
chlorides: synthesis, characterization and ethylene polymerization, Sci. China Chem. 59 (2016) 1291-1300.

21. W. Zhao, E. Yue, X. Wang, W. Yang, Y. Chen, X. Hao, X. Cao, W.-H. Sun, Activity and stability spontaneously enhanced toward ethylene polymerization by employing 2-(1-(2,4dibenzhydrylnaphthylimino)ethyl)-6-(1-(arylimino)ethyl) pyridyliron(II) dichlorides, J. Polym. Sci., Part A: Polym. Chem. 55 (2017) 988-996.

22. L. Wang, W.-H. Sun, L. Han, H. Yang, Y. Hu, X. Jin, Late transition metal complexes bearing 2,9-bis(imino)-1,10-phenanthrolinyl ligands: synthesis, characterization and their ethylene activity, J. Organomet. Chem. 658 (2002) 62-70.

23. W.-H. Sun, S. Jie, S. Zhang, W. Zhang, Y. Song, H. Ma, Iron complexes bearing 2-imino1,10-phenanthrolinyl ligands as highly active catalysts for ethylene oligomerization, Organometallics. 25 (2006) 666-677.

24. J. D. A. Pelletier, Y. D. M. Champouret, J. Cardarso, L. Clowes, M. Gañete, K. Singh, V. Thanarajasingham, G. A. Solan, Electronically variable imino-phenanthrolinyl-cobalt complexes; synthesis, structures and ethylene oligomerisation studies, J. Organomet. Chem. 691 (2006) 4114-4123.

25. S. Jie, S. Zhang, K. Wedeking, W. Zhang, H. Ma, X. Lu, Y. Deng, W.-H. Sun, Cobalt (II) complexes bearing 2-imino-1,10-phenanthroline ligands: synthesis, characterization and ethylene oligomerization, C. R. Chim. 9 (2006) 1500-1509.

26. S. Jie, S. Zhang, W.-H. Sun, X. Kuang, T. Liu, J. Guo, Iron(II) complexes ligated by 2imino-1,10-phenanthrolines: Preparation and catalytic behavior toward ethylene oligomerization, J. Mol. Cat. A: Chem. 269 (2007) 85-96.

27. S. Jie, S. Zhang, W.-H. Sun, 2-arylimino-9-phenyl-1,10-phenanthrolinyl-iron, -cobalt and nickel complexes: Synthesis, characterization and ethylene oligomerization behavior, Eur. J. Inorg. Chem. (2007) 5584-5598. 
28. W.-H. Sun, P. Hao, S. Zhang, Q. Shi, W. Zuo, X. Tang, Iron(II) and cobalt(II) 2(benzimidazolyl)-6-(1-(arylimino)ethyl)pyridyl complexes as catalysts for ethylene oligomerization and polymerization, Organometallics. 26 (2007) 2720-2734.

29. Y. Chen, P. Hao, W. Zuo, K. Gao, W.-H. Sun, 2-(1-Isopropyl-2-benzimidazolyl)-6-(1aryliminoethyl)pyridyl transition metal (Fe, Co, and Ni) dichlorides: Syntheses, characterizations and their catalytic behaviors toward ethylene reactivity, J. Organomet. Chem. 693 (2008) 1829-1840.

30. L. Xiao, R. Gao, M. Zhang, Y. Li, X. Cao, W.-H. Sun, 2-(1H-2-Benzimidazolyl)-6-(1(arylimino)ethyl)pyridyl iron(II) and cobalt(II) dichlorides: Syntheses, characterizations, and catalytic behaviors toward ethylene reactivity, Organometallics. 28 (2009) 2225-2233.

31. R. Gao, Y. Li, F. Wang, W.-H. Sun, M. Bochman, 2-benzoxazolyl-6-[1(arylimino)ethyl]pyridyliron (II) chlorides as ethylene oligomerization catalysts, Eur. J. Inorg. Chem. (2009) 4149-4156.

32. K. Wang, K. Wedeking, W. Zuo, D. Zhang, W.-H. Sun, Iron(II) and cobalt(II) complexes bearing N-((pyridin-2-yl)methylene)-quinolin-8-amine derivatives: Synthesis and application to ethylene oligomerization, J. Organomet. Chem. 693 (2008) 1073-1080.

33. S. Zhang, W.-H. Sun, T. Xiao, X. Hao, Ferrous and cobaltous chlorides bearing 2,8bis(imino)quinolines: highly active catalysts for ethylene polymerization at high temperature, Organometallics. 29 ( 2010) 1168-1173.

34. Z. Wang, G. A. Solan, W. Zhang, W.-H. Sun, Carbocyclic-fused $N, N, N$-pincer ligands as ring-strain adjustable supports for iron and cobalt catalysts in ethylene oligo/polymerization, Coord. Chem. Rev. 363 (2018) 92-108.

35. V. K. Appukuttan, Y. Liu, B. C. Son, C.-S. Ha, H. Suh, I. Kim, Iron and cobalt complexes of 2,3,7,8-tetrahydroacridine-4,-5(1H,6H)-diimine sterically modulated by substituted aryl rings for the selective oligomerization to polymerization of ethylene, Organometallics. 30 (2011) 2285-2294. 
36. W. Zhang, W. Chai, W.-H. Sun, X. Hu, C. Redshaw, X. Hao, 2-(1-(arylimino)ethyl)-8arylimino-5,6,7-trihydroquinoline iron(II) chloride complexes: Synthesis, characterization, and ethylene polymerization behavior, Organometallics. 31 (2012) 5039-5048.

37. W.-H. Sun, S. Kong, W. Chai, T. Shiono, C. Redshaw, X. Hu, C. Guo, X. Hao, 2-(1(arylimino)ethyl)-8-arylimino-5,6,7-trihydroquinolylcobalt dichloride: Synthesis and polyethylene wax formation, Appl. Catal. A. 447-448 (2012) 67-73.

38. F. Huang, Q. Xing, T. Liang, Z. Flisak, B. Ye, X. Hu, W. Yang, W.-H. Sun, 2-(1aryliminoethyl)-9-arylimino-5,6,7,8-tetrahydrocycloheptapyridyl iron(II) dichloride: synthesis, characterization, and the highly active and tunable active species in ethylene polymerization, Dalton Trans. 43 (2014) 16818-16829.

39. F. Huang, W. Zhang, E. Yue, T. Liang, X. Hu, W.-H. Sun, Controlling the molecular weights of polyethylene waxes using the highly active precatalysts of 2-(1-aryliminoethyl)9-arylimino-5,6,7,8-tetrahydrocycloheptapyridylcobalt chlorides: Synthesis, characterization, and catalytic behavior, Dalton Trans. 45 (2016) 657-666.

40. S. Du, X. Wang, W. Zhang, Z. Flisak, Y. Sun, W.-H. Sun, A practical ethylene polymerization for vinyl-polyethylenes: synthesis, characterization and catalytic behavior of $\alpha, \alpha^{\prime}$-bisimino-2,3:5,6-bis(pentamethylene)pyridyliron chlorides, Polym. Chem.7 (2016) $4188-4197$.

41. S. Du, W. Zhang, E. Yue, F. Huang, T. Liang, W.-H. Sun, $\alpha, \alpha^{\prime}$-Bis(arylimino)-2,3:5,6bis(pentamethylene)pyridylcobalt chlorides: Synthesis, characterization, and ethylene polymerization behavior, Eur. J. Inorg. Chem. (2016) 1748-1755.

42. C. Huang, S. Du, G. A. Solan, Y. Sun, W.-H. Sun, From polyethylene waxes to HDPE using a $\alpha, \alpha^{\prime}$-bis(arylimino)-2,3:5,6-bis(pentamethylene)pyridyl-chromium(III) chloride precatalyst in ethylene polymerisation, Dalton Trans. 46 (2017) 6948-6957.

43. F. Huang, W. Zhang, Y. Sun, X. Hu, G. A. Solan, W.-H. Sun, Thermally stable and highly active cobalt precatalysts for vinyl-polyethylenes with narrow polydispersities: Integrating 
fused-ring and imino-carbon protection into ligand design, New J. Chem. 40 (2016) 80128023.

44. Y. Zhang, H. Suo, F. Huang, T. Liang, X. Hu, W.-H. Sun, Thermo-stable 2(arylimino)benzylidene-9-arylimino-5,6,7,8-tetrahydrocyclohepta[b]pyridyliron precatalysts toward ethylene polymerization and highly linear polyethylenes, J. Polym. Sci, Part A: Polym. Chem. 55 (2017) 830-842.

45. Z. Wang, G. A. Solan, Q. Mahmood, Q. Liu, Y. Ma, X. Hao, W.-H. Sun, Bis(imino)pyridines incorporating doubly fused eight-membered rings as conformationally flexible supports for cobalt ethylene polymerization catalysts, Organometallics. 37 (2018) 380-389.

46. H. Suo, I. I. Oleynik, C. Bariashir, I. V. Oleynik, Z. Wang, G. A. Solan, Y. Ma, T. Liang, W.-H. Sun, Strictly linear polyethylene using Co-catalysts chelated by fused bis(arylimino)pyridines: Probing ortho-cycloalkyl ring-size effects on molecular weight, Polymer. 149 (2018) 45-54.

47. J. Ba, S. Du, E. Yue, X. Hu, Z. Flisak, W.-H. Sun, Constrained formation of 2-(1(arylimino)ethyl)-7-arylimino-6,6-dimethylcyclopentapyridines and their cobalt (II) chloride complexes: synthesis, characterization and ethylene polymerization, RSC Adv. 5 (2015) 32720-32729.

48. C. Bariashir, Z. Wang, S. Du, G. A. Solan, C. Huang, T. Liang, W.-H. Sun, Cycloheptylfused NNO-ligands as electronically modifiable supports for $\mathrm{M}(\mathrm{II})(\mathrm{M}=\mathrm{Co}, \mathrm{Fe})$ chloride precatalysts; probing performance in ethylene oligo-/polymerization, J. Polym. Sci. A Polym. Chem. 55 (2017) 3980-3989.

49. R. P. Thummel, Y. Jahng, polyaza cavity shaped molecules. 4. Annelated derivatives of 2,2':6',2"-terpyridine, J. Org. Chem. 50 (1985) 2407-2412. 
50. R. P. Thummel, F. Lefoulon, D. Cantu, R. Mahadevan, Polyaza cavity-shaped molecules. Annelated derivatives of 2-(2'-pyridyl)-1,8-naphthyridine and 2,2'-bi-1,8-naphthyridine, J. Org. Chem. 49 (1984) 2208-2212.

51. S. Meiries, K. Speck, B. D. Cordes, A. M. Z. Slawin, S. P. Nolan, [Pd(IPr*OMe)(acac)Cl]: tuning the $\mathrm{N}$-heterocyclic carbene in catalytic $\mathrm{C}-\mathrm{N}$ bond formation, Organometallics. 32 (2013) 330-339.

52. P. Shaw, A. R. Kennedy, D. J. Nelson, Synthesis and characterisation of an N-heterocyclic carbene with spatially-defined steric impact, Dalton Trans. 45 (2016) 11772-11780.

53. G. M. Sheldrick, SHELXT - integrated space-group and crystal structure determination, Acta Cryst. A71 (2015) 3-8.

54. G. M. Sheldrick, Crystal structure refinement with SHELXL, Acta Cryst. C71 (2015) 3-8.

55. G. J. P. Britovsek, S. Mastroianni, G. A. Solan, S. P. D. Baugh, C. Redshaw, V. C. Gibson, A. J. P. White, D. J. Williams, M. R. J. Elsegood, Oligomerisation of ethylene by bis(imino)pyridyliron and -cobalt complexes, Chem. Eur. J. 6 (2000) 2221-2231.

56. F. Ragaini, M. Gasperine, E. Gallo, P. Machchi, Using ring strain to inhibit a decomposition path: first synthesis of an Alkyl-BIAN ligand (Alkyl-BIAN 5 bis(alkyl)acenaphthenequinonediimine), Chem. Commun. (2005) 1031-1033.

57. T. Xiao, P. Hao, G. Kehr, X. Hao, G. Erker, W.-H. Sun, Dichlorocobalt (II) complexes ligated by bidentate 8-(benzoimidazol-2-yl)quinolines: Synthesis, characterization, and catalytic behavior toward ethylene, Organometallics. 30 (2011) 4847-4853.

58. W.-H. Sun, X. Tang, T. Gao, B. Wu, W. Zhang, H. Ma, Synthesis, characterization, and ethylene oligomerization and polymerization of ferrous and cobaltous 2(ethylcarboxylato)-6-iminopyridyl complexes, Organometallics. 23 (2004) 5037 - 5047.

59. Q. Chen, W. Zhang, G. A. Solan, T. Liang, W.-H. Sun, Methylene-bridged bimetallic bis(imino)pyridinecobaltous chlorides as precatalysts for vinylterminated polyethylene waxes, Dalton Trans. (2018) 6124-6133. 